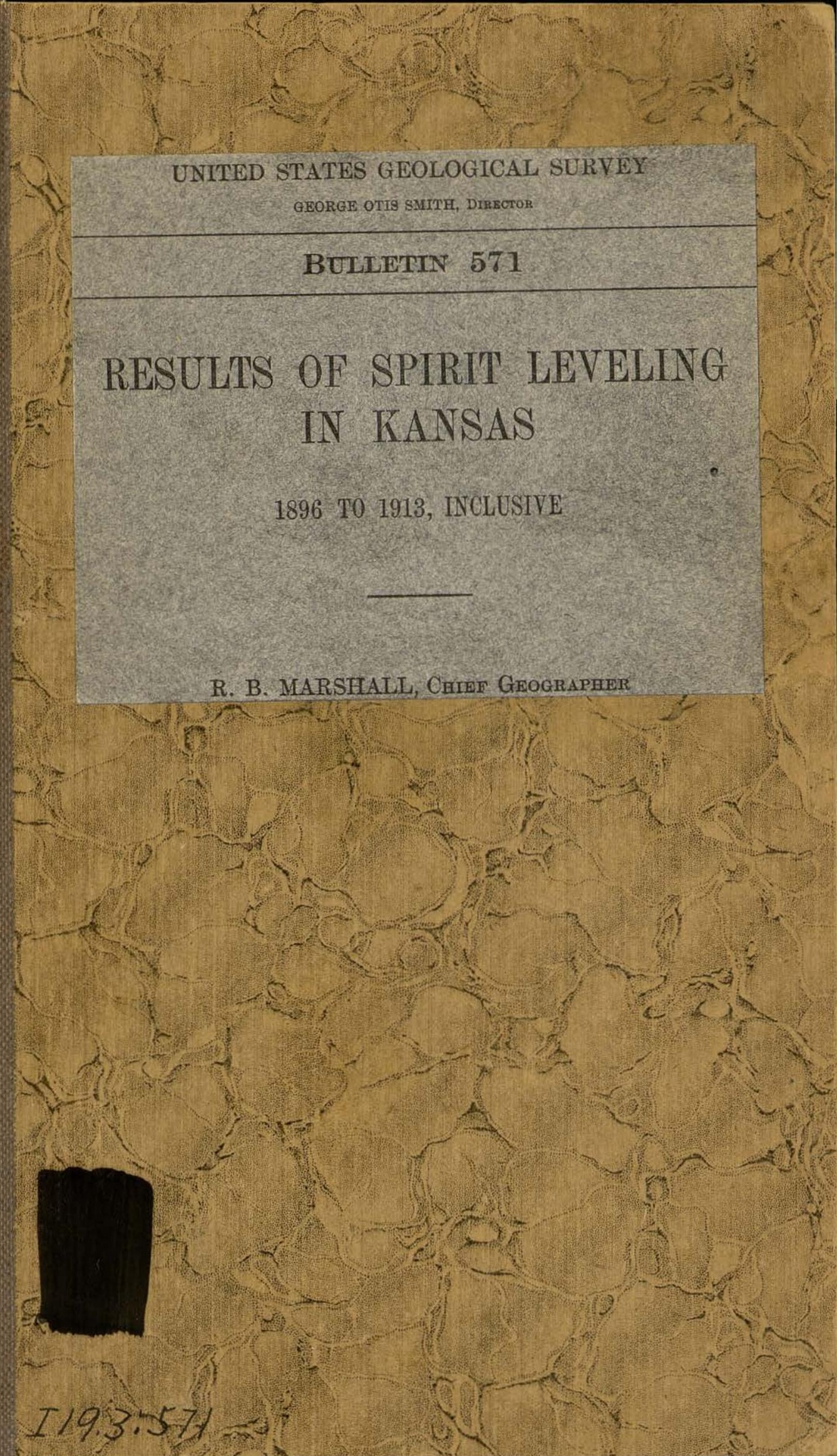


TEXAS TECH UNIVERSITY

3 1295013473375 


\section{$A D E-0006$}

DEPARTMENT OF THE INTERIOR

UNITED STATES GEOLOGICAL SURVEY

GEORGE OTIS SMITH, DIRECTOR

\section{BULLeTIN 571}

\section{RESULTS OF SPIRIT LEVELING IN KANSAS}

1896 T0 1913, INCLUSIVE

R. B. MARShaLL, Chief Geographer

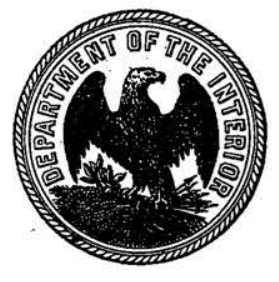

LIBRARY

TEXAS TECHNOLOGICAL COLLEGE LUBBOCK, TEXAS

WASHINGTON

GOVERNMENT PRINTING OFFIOE

1914 



\section{CONTENTS.}

Page.

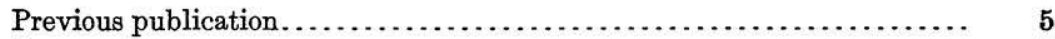

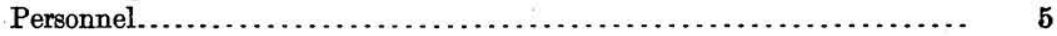

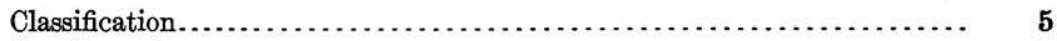

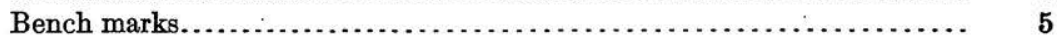

Datum.................................................... 6

Topographic maps............................................... 7

Primary leveling................................................. 8

Joplin district (Cherokee County) ............................... 8

Iola and Parsons quadrangles (Allen, Bourbon, Crawford, Labette, and Neosho counties) ......................................... 8

Independence quadrangle (Montgomery and Wilson counties).......... 10

Atchison, Kansas City, and Oskaloosa $30^{\prime}$ quadrangles, including Easton and Leavenworth $15^{\prime}$ quadrangles (Atkins and Leavenworth counties)..

Garden, Lakin, Syracuse, and Tribune quadrangles (Finney, Grant, Hamil-

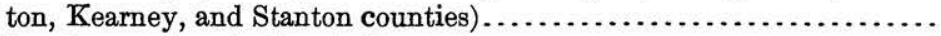

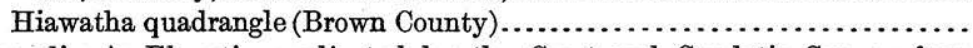
Appendix A: Elevations adjusted by the Coast and Geodetic Survey from

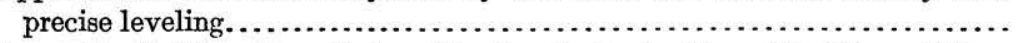
Appendix B: Elevations of stone-line bench marks along the Missouri River established by the Missouri River Commission by primary leveling..........

\section{ILLUSTRATION.}

Plate I. Geological Survey bench marks. 




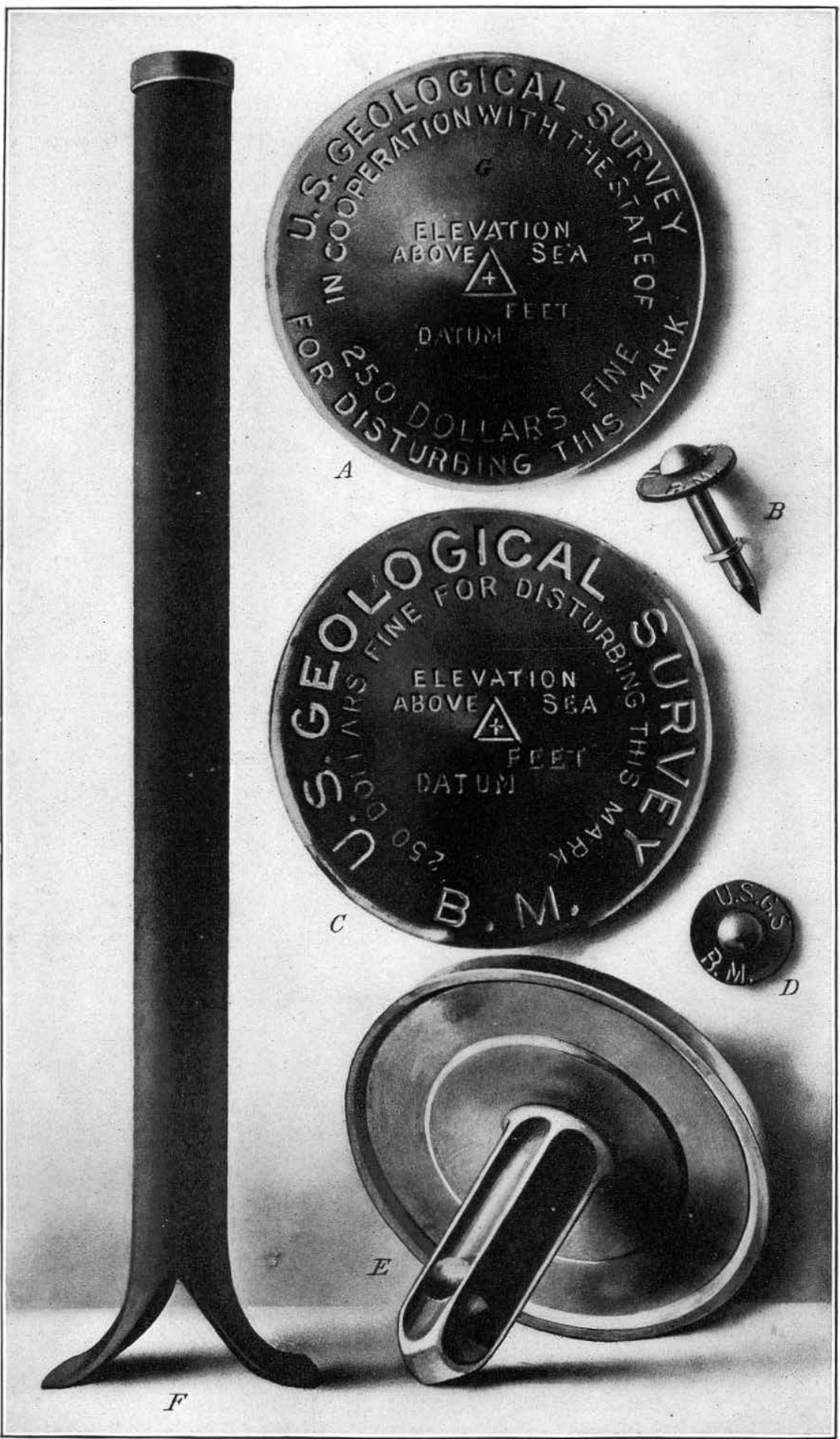

GEOLOGICAL SURVEY BENCH MARKS.

$A$, Tablet used in cooperating States. The State name is inserted at $G$.

$B$ and $D$, Copper temporary bench mark, consisting of a nail and copper washer.

$A, C$, and $E$, Tablets for stone or concrete structures.

$F$, Iron post used where there is no rock. 


\section{RESULTS OF SPIRIT LEVELING IN K̇ANSAS FROM 1896 TO 1913, INCLUSIVE.}

R. B. Marshall, Chief Geographer.

\section{INTRODUCTION.}

Previous publication.-All results of spirit leveling in Kansas published by the United States Geological Survey in Bulletin 473 and all the results of later work are included in this report. Elevations are based on heights of bench marks along precise-level lines of the Coast and Geodetic Survey and of the Missouri River Commission, as adjusted in 1912 by the Coast and Geodetic Survey, and are likely to be changed but slightly by any future adjustment. The elevations of bench marks in the western part of the State are based on railroad data, and are, therefore, only approximate.

Personnel.- The field work before 1903 was done under the general direction of J. H. Renshawe, geographer; that for 1903 to 1906, inclusive, under H. M. Wilson, geographer; and the later work under W. H. Herron, geographer, and since 1908 under the general supervision of R. B. Marshall, chief geographer. The names of the various levelmen are given in the introductions to the several lists. The office work of computation, adjustment, and preparation of lists was done mainly by S. S. Gannett, geographer, under the general direction of E. M. Douglas, geographer.

Classification.-No precise leveling has been done by the United States Geological Survey in Kansas. For primary lines standard $Y$ levels are used; lines are run in circuits or are closed on precise lines, with an allowable closing error in feet represented by $0.05 \sqrt{\bar{D}}$, in which $\mathrm{D}$ is the length of the circuit in miles, sufficient care being given to the work to maintain this standard. For levels of this class careful office adjustments are made, the circuit errors being distributed over the lines.

Bench marks. -The standard bench marks are of two forms. The first form is a circular bronze or aluminum tablet ( $C$ and $E, \mathrm{Pl}$. I), $3 \frac{1}{2}$ inches in diameter and one-quarter inch thick, having a 3-inch stem, which is cemented in a drill hole in solid rock in the wall of some public building, a bridge abutment, or other substantial masonry structure. The second form ( $F, \mathrm{Pl}$. I), used where masonry or rock is not available, consists of a hollow wrought-iron post $3 \frac{1}{2}$ inches in 
outer diameter and 4 feet in length. The bottom is spread out to a width of 10 inches in order to give a firm bearing on the earth. A bronze or aluminum-bronze cap is riveted over the top of the post, which is set about 3 feet in the ground. A third style of bench mark with abbreviated lettering ( $B$ and $D, \mathrm{Pl} . \mathrm{I}$ ) is used for unimportant points. This consists of a special copper nail $1 \frac{1}{2}$ inches in length driven through a copper washer seven-eighths inch in diameter. The tablets, as well as the caps on theiron posts, are appropriately lettered, and cooperation by States is indicated by the addition of the State name $(G, \mathrm{Pl}$. I).

The numbers stamped on the bench marks described in the following pages represent the elevations to the nearest foot as determined by the levelman. These numbers are stamped with $\frac{3}{16}$-inch steel dies on the tablets or post caps, to the left of the word "feet." The office adjustment of the notes and the reduction to mean sea-level datum may so change some of the figures that the original markings are 1 or 2 feet in error. It is assumed that engineers and others who have occasion to use the bench-mark elevations will apply to the Director of the United States Geological Survey, at Washington, D. C., for the adjusted values, and will use the markings as identification numbers only.

Datum.-All United States Geological Survey elevations are referred to mean sea level, which is the level that the sea would assume if the influence of winds and tides were eliminated. This level is not the elevation determined from the mean of the highest and the lowest tides, nor is it the half sum of the mean of all the high tides and the mean of all the low tides, which is called the half-tide level. Mean sea level is the average height of the water, all stages of the tide being considered. It is determined from observations made by means of tidal gages placed at stations where local conditions, such as long, narrow bays, rivers, and like features, will not affect the height of the water. To obtain even approximately correct results these observations must extend over at least one lunar month, and if accuracy is desired they must extend over several years. At ocean stations the half-tide level and the mean sea level usually differ but little. It is assumed that there is no difference between the mean sea level as determined from observations in the Atlantic Ocean, the Gulf of Mexico, or the Pacific Ocean.

The connection with tidal stations for bench marks in certain areas that lie at some distance from the sea coast is still uncertain, and this fact is indicated by the addition of a letter or word to the right of the word "datum" on tablets or posts. For such areas corrections for published results will be made from time to time as the preciselevel lines of the United States Geological Survey or other Government organizations are extended. 
Topographic maps.-Maps of the following quadrangles wholly or partly in Kansas have been published by the United States Geological Survey up to May 1, 1914. They may be obtained, except as noted, for 10 cents each or $\$ 3$ for 50 , on application to the Director of the Survey at Washington, D. C.

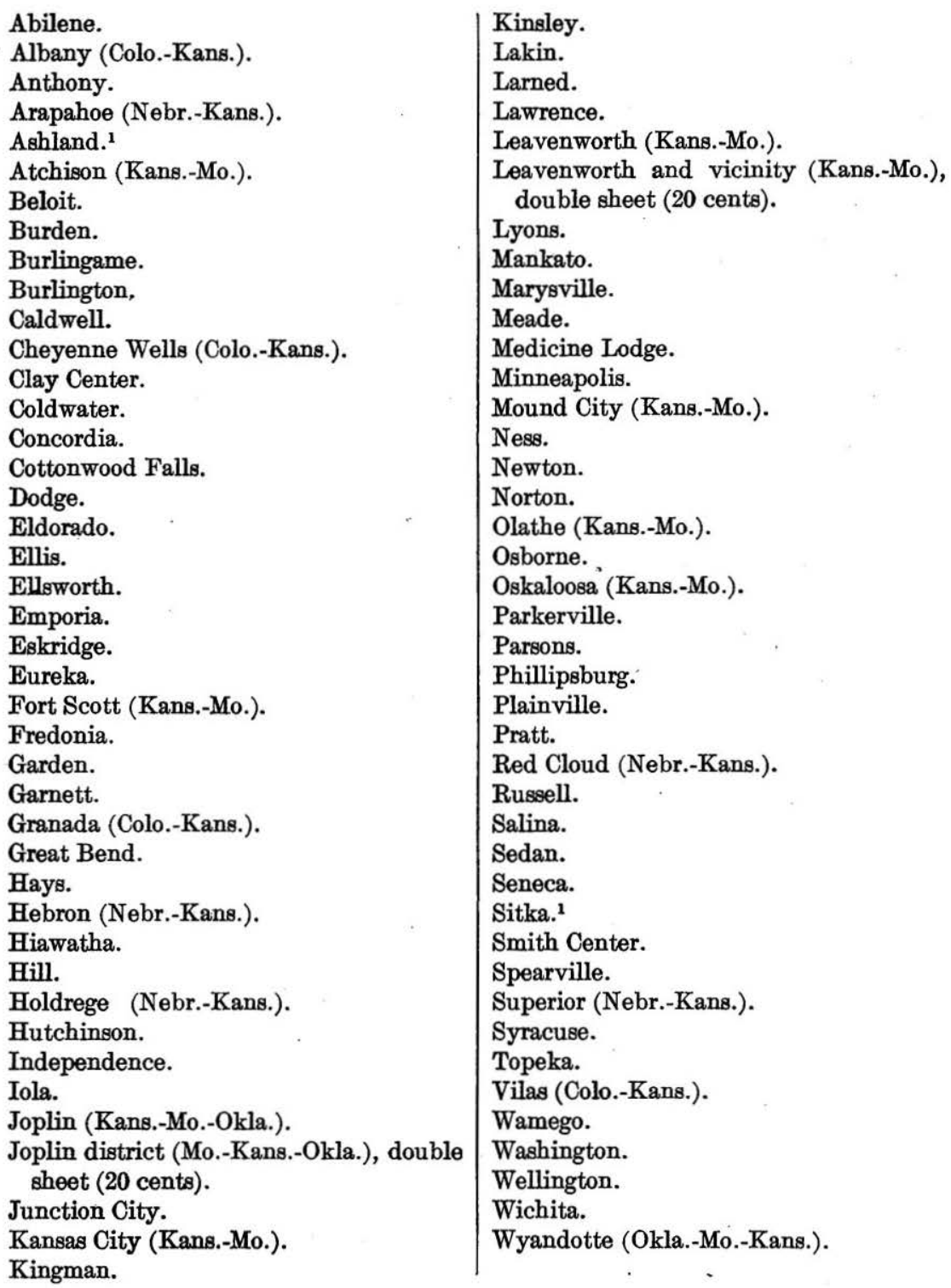

1 Sitka sheet, on scale of 1:62500, has been reduced and forms part of Ashland sheet, on scale of 1:125000. 
SPIRIT LEVELING IN KANSAS, 1896-1913.

\title{
PRIMARY LEVEHING.
}

Joplin district.

CHEROKEE COUNTY.

The elevations published in the following list are based on bench mark "CIII" of the Coast and Geodetic Survey at Carthage, Mo., at the southwest corner of Main and Limestone streets, a cross cut on the rounded top of a 6 by 6 inch limestone post buried in the ground 2.3 feet west of intersection of the inside lines of sidewalk. The elevation of this bench mark, as corrected by the 1912 adjustment of that Survey, is accepted as 941.645 feet above mean sea level.

The leveling was done in 1904 by D. C. Wray.

All bench marks dependent upon this datum are stamped with the letters "Crthg" in addition to the figures of elevation.

For additional data for the same area see Bulletin 568, "Results of spirit leveling in Missouri."

\author{
JOPIIN DISTRICT. \\ [Latitude $37^{\circ}-37^{\circ} 15^{\prime}$; longitude $94^{\circ} 15^{\prime}-94^{\circ} 45^{\prime}$.]
}

T. 35 S., R. 25 E., northeast corner of sec. 11, 24 feet west of corner stone; Feet. iron post stamped " 1016 Crthg" .............................. 1, 015.667

Galena, west side of Euclid Avenue, between Seventh and Eighth streets, 2 feet north of southeast corner of foundation of schoolhouse; aluminum tablet stamped " 976 Crthg". ................................

Baxter Springs, 51 feet west of southeast corner of city hall, in third course of stone below water table; aluminum tablet stamped " 842 Crthg"....

T. 33 S., R. 25 E., SE. $\frac{1}{4}$ sec. 12, 45 feet south of corner stone, at west side of State line road; iron post stamped " 914 Crthg". . . . . ..............

T. 32 S., R. 25 E., northwest corner of sec. 19, 4 feet east of corner fence post, southeast of crossroads; iron post stamped " 904 Crthg"............

T. 33 S., R. 24 E., northeast corner of sec. 1, 40 feet south and 15 feet west of corner stone in center of crossroads; iron post stamped " 893 Crthg"..

T. 34 S., R. 24 E., northeast corner of sec. 1, 40 feet south and 30 feet west of corner stone in center of crossroads; iron post stamped "862 Crthg"..

Iola and Parsons quadrangles.

ALLEN, BOURBON, CRAWFORD, LABETTE, AND NEOSHO COUNTIES.

The elevations in the following list are based on an aluminum tablet stamped "968 Iola," in the northeast corner of Northup's National Bank building at Iola, Kans., the elevation of which is accepted as 971.089 feet above mean sea level. The initial point upon which this work depends is the bronze tablet established by the Indian Territory levels in the school building at Chetopa, Kans., the elevation of which as now accepted is 4.450 feet higher than published in Bulletin 175.

The leveling was done in 1902 by Fox Wood. 
PARSONS QUADRANGLE.

[Latitude, $37^{\circ}-37^{\circ} 30^{\prime}$; longitude, $95^{\circ}-95^{\circ} 30^{\prime}$.]

From Chetopa north along Missouri, Kansas \& Texas Ry. to Erle, thence along highway to La Harpe. (Double-rodded line.)

Erie, in east wing of courthouse; bronze tablet stamped "892 Iola".

Feet.

894.680

T. 26 S., R. 20 E., northeast corner of sec. 31 , in north end of stone pier at south end of iron bridge over Big Creek; aluminum tablet stamped " 940 Iola".

T 25 S., R. 19 E., southeast corner of sec. 36, in south side of schoolhouse, near corner of sections; bronze tablet stamped "1068 Iola".......... 1,070. 893

T. 24 S., R. 19 E., southeast corner of sec. 36; iron post stamped " 1032 Iola"

\section{IOLA QUADRANGLE.}

[Latitude, $37^{\circ} 30^{\prime}-38^{\circ}$; longitude, $95^{\circ}-95^{\circ} 30^{\prime}$.]

From Erie along highway east and around Tps. 27 and 28 S., R. 21 E.

T. 29 S., R. 21 E., 0.25 mile east of northwest corner of sec. 6, north side of schoolhouse; bronze tablet stamped " 896 Iola".

T. $28 \mathrm{~S}$., R. 22 E., 0.25 mile south of northwest corner of sec. 31, east side of road, north end of bridge over Big Walnut Creek, in rock abutment; bronze tablet stamped "897 Iola".

898. 675

T. 27 S., R. 21 E., southeast corner of sec. 36 ; iron post stamped "952 Iola".

899.842

Portersville, northeast corner of schoolhouse; aluminum tablet stamped "1008 Iola".

954. 771

Savonburg, in west wing of schoolhouse; bronze tablet stamped " 1057 Iola"

T. 27 S., R. 20 E., southeast corner of sec. 36 ; iron post stamped " 1022 Iola"

T. 27 S., R. 19 E., southeast corner of sec. 36 , in northeast corner of church; bronze tablet stamped "1004 Iola"......................... 1,006. 732

T. 26 S., R. 18 E., southeast corner of sec. 36; iron post stamped " 997 Iola"

North Valley, southeast corner of sec. 36, T. 27 S., R. 18 E., in southeast corner of schoolhouse; bronze tablet stamped "909 Iola".

910. 914

From northeast corner of T. 26 S., R. 19 E., west through Humboldt and south along range line between Rs. 17 and 18 E., thence along township line between Tps. 28 and $29 \mathrm{~s}$.

Humboldt, 3 miles east of, northwest corner of Central Avenue school-

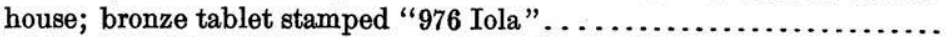

T. 26 N., R. 18 E., southwest corner of sec. 30 , in southwest corner of schoolhouse; aluminum tablet stamped " 953 Iola".

979. 212

T. 27 S., R. 17 E., southeast corner of sec. 36 ; iron post stamped " 981 Iola".

955.423

T. 28 S., R. 17 E., southeast corner of sec. 36; iron post stamped " 957 Iola"

Urbana, southeast corner of church; aluminum tablet stamped "954 Iola".

T. 24 S., R. 20 E., southeast corner of sec. 36; iron post stamped "1091 Iola"

983. 509

959. 738

956. 904

T. 24 S., R. 21 E., southeast corner of sec. 36; iron post stamped " 1062 Iola" 
T. 23 S., R. 21 E., southeast corner of sec. 36; iron post stamped "1043 Feet.

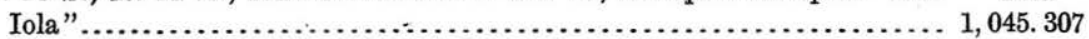

T. 24 S., R. 20 E., northeast corner of sec. 1, on north side of schoolhouse; bronze tablet stamped "1024 Iola"........................... 1,026. 743

T. 24 S., R. 20 E., sec. 7; northwest corner of schoolhouse; bronze tablet stamped "1059 Iola" ..................................... 1,061.641

From La Harpe west along rallroad and highway and around T. 25 S., Rs. 18 and $19 \mathrm{E}$.

Iola, in northwest corner of Northup's National Bank building; bronze tablet stamped "968 Iola"..................................

T. 24 S., R. 17 E., southeast corner of sec. 25; iron post stamped "1010 Iola "................................................ 1, 012.342

T. 23 S., R. 18 E., southeast corner of sec. 31; iron post stamped " 1050

Iola "............................................... 1,052.460

T. 23 S., R. 19 E., northeast corner of sec. 1, in northeast corner of schoolhouse; bronze tablet stamped " 1022 Iola". . . . . . . . . . . . . . . . . 1, 024.445

Independence quadrangle.

MONTGOMERY AND WILSON COUNTIES.

The elevations in the following list are based on an aluminum tablet stamped "824 Independence," in the northwest corner of the courthouse at Independence, Kans., the elevation of which is accepted as 827.237 feet above mean sea level. The initial point upon which these levels depend is the bronze tablet established by the Indian Territory (now part of Oklahoma) levels at Coffeyville, Kans., the present accepted elevation of which is 4.454 feet higher than that published on page 88, in Bulletin 175 .

The leveling was done in 1903 by Fox Wood.

INDEPENDENCE QUADRANGLE.

[Latitude, $37^{\circ}-37^{\circ} 30^{\prime}$; longitude, $95^{\circ} 30^{\prime}-96^{\circ}$.]

From Cofieyville west along highway 6 miles to Deering, thence north 30 miles, thence east 6 miles, thence south to Coffeyville. 1

Coffeyville, Ried Building; bronze tablet stamped "731 Independence." Feet.

(See Indian Territory levels, Bulletin 175)....................

Coffeyville, 4 miles west of, on township line, south side of bridge across

Onion Creek, in east pier; chiseled cross.........................

Deering, in southwest corner of store of H. L. Towles; aluminum tablet stamped "763 Independence".................................

T. 34 S., R. 16 E., northwest corner of sec. 6, in northwest corner of Meyers's residence; aluminum tablet stamped " 882 Independence".

Independence, northwest corner of courthouse; aluminum tablet stamped "824 Independence".

735.826

740. 39

766.554

884. 484

827. 237

Sycamore, southeast corner of schoolhouse; aluminum tablet stamped "829

Independence".

831. 447

Neodesha, southeast corner of Fourth and Main streets, in north side of brick building (Dr. F. T. Allen's store); aluminum tablet stamped " 817 Independence",

Tps. 29 and 30 S., R. 16 E., on line between secs. 3 and 34,12 feet from east rail, in east end of concrete railroad culvert; aluminum tablet stamped "842 Independence". 
T. 30 S., R. 17 E., 0.25 mile east of northwest corner of sec. 6 , in northeast corner of Mrs. Ann Clegg's house; aluminum tablet stamped "871 Independence"

Feet.

873. 666

904.004

895. 124

761.741

760.977

"757 Independence"

From Deering west along highway 6 miles to Fawn, thence north about 30 miles to sec. 35, T. 29 S., R. 14 E., thence west 2 miles; return line south from Elk City and Havana to southwest corner of T. 24 S., R. 14 E., thence east 6 miles to Fawn.

Tyro, in northeast corner of schoolhouse; aluminum tablet stamped "896 Independence." (Reported destroyed in 1909)....................

T. 33 S., R. 15 E., sec. 36, in northwest corner of schoolhouse; aluminum tablet stamped "831 Independence"............................

T. 32 S., R. 15 E., northwest corner of sec. 30, in northwest corner of schoolhouse; aluminum tablet stamped "821 Independence".

T. 31 S., R. 14 E., near sec. 23, southeast corner of schoolhouse; aluminum tablet stamped "918 Independence".

La Fontaine, in southeast corner of schoolhouse; aluminum tablet stamped "918 Independence".

T. 29 S., R. 14 E., near sec. 36, in southwest corner of schoolhouse; aluminum tablet stamped "928 Independence".

Buxton, northeast corner of Christian Church; aluminum tablet stamped "979 Independence".

T. 30 S., R. 14 E., sec. 33, in northwest corner of Henry Cox's residence; aluminum tablet stamped "891 Independence"...................

Elk City, in wing of brick schoolhouse; aluminum tablet stamped "833 Independence".

T. 32 S., R. 14 E., sec. 30, residence of C. Curtis, in west foundation of front porch; aluminum tablet stamped "853 Independence".

Havana, in schoolhouse; aluminum tablet stamped "762 Independence"

T. 34 S., R. 14 E., sec. 31, in south side of house of M. M. Freidlin; aluminum tablet stamped "757 Independence".

898. 227

833. 233

823. 242

920. 226

920. 331

930. 112

980.984

893. 236

835. 487

855. 432

763. 778

759. 195

Atchison, Kansas City, and Oskaloosa $30^{\prime}$ quadrangles, including Easton and Leavenworth $15^{\prime}$ quadrangles.

\section{ATKINS AND LEAVENWORTH COUNTIES.}

The elevations are based on bench marks of the Missouri River Commission.

The leveling was done by S. K. Atkinson in 1906 and by G. E. Heebink in 1908-9. 


\section{RANSAS CITY QUADRANGLE.}

[Latitude, $39^{\circ}-39^{\circ} 30^{\prime}$; longitude, $94^{\circ} 30^{\prime}-95^{\circ}$.]

Standard bench mark of the Missouri River Commission.

Connor, about 2.5 miles above, 1,265 feet below first road crossing below Popes Siding, 1,315 feet below bridge 79, across small creek, 220 feet above center of small bridge where the Gilman or bottom road turns east away from track, about 0.5 mile east of houses of $\mathrm{E}$. Piper and $\mathrm{Mr}$. Tull, 33 feet west of center of track on line of right of way; copper bolt in bench-mark stone (Mo. R. Comm. p. b. m. 247).

Feet.

755. 428

759.477

801.89

881.58

927. 11

859. 655

877.50

961.785

954. 94

$1,017.59$

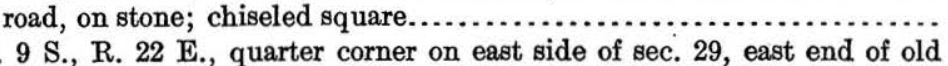
Lawrence road; iron pipe set 3 feet in ground and projecting 1 foot above ground, stamped " 1043 ".

T. 9 S., R. 22 E., southwest corner of sec. 20 , on granite bowlder; chiseled square marked " 966 "

Boling, 1 mile northeast of, on southeast corner of Atchison, Topeka \& Santa Fe Ry. bridge 17; bolt painted white and marked "U. S. 914"...

913. 42

LEAVENWORTH 15' (KANSAS CITY 30') QUADRANGLE.

[Latitude, $39^{\circ} 15^{\prime}-39^{\circ} 30^{\prime}$; longitude, $94^{\circ} 45^{\prime}-95^{\circ}$.]

From Leavenworth west to Hund, thence south 1 mile.

Hund, 40 feet south of Union Pacific R. R. tracks, 20 feet west of wagon road; iron post stamped " 834 "

832. 721

Hund, 1 mile south of, on stone abutment of steel bridge 130; chiseled square marked " 846 ".

OSKALOOSA QUADRANGLE.

[Latitude, $39^{\circ}-39^{\circ} 30^{\prime}$; longitude, $95^{\circ}-95^{\circ} 30^{\prime}$.]

From Springdale south to Ackerland, thence east along ralload to Boling.

Springdale, 1.5 miles south of, at crossroads near mail box 60 , in north root of forked oak tree; nail.

Ackerland, 1 mile north of, northeast corner of sec. 36, T. 9 S., R. 20 E.; section stone marked " 1006 ". 
Ackerland, 300 feet east of station, intersection of railroad with main north- Feet. south pike; point on track, marked "1041".

Ackerland, 1 mile east of, 2 miles west of Jarbalo, on southwest corner of railroad bridge 32 ; bolt painted white and marked "U. S. 971 "..........

Milepost 15; top of rail........................................

Jarbalo, 1 mile west of, railroad crossing; joint on south rail, marked " 919 ".

Jarbalo, 120 feet east of station, 30 feet south of tracks; iron post stamped "871".

970. 29

965. 36

917. 95

Jarbalo, 1 mile east of, southwest corner of bridge 29 ; bolt painted white and marked " 857 ".

870.623

856. 15

Jarbalo, 2 miles east of, in southeast corner of bridge 26 ; bolt painted white and marked " 866 ".

864.45

873. 59

Milepost 11; top of vertical rail

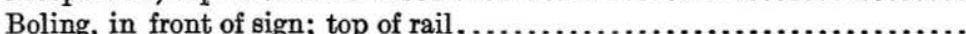

Boling, 200 feet northeast of station, 3 feet south of main track; large iron cylinder set in ground, marked "U. S. 914"

916. 0

912. 77

From corner of secs. 14, 15, 22, and 23, T. 9 S., R. 20 E., south 1.5 miles, thence west 2.5 miles, thence north to sec. 17.

T. 9 S., R. 20 E., quarter corner between secs. 26 and 27, 5.2 feet from ground, near crotch in 20-inch elm tree at T road; 40-penny nail........ 997.60

T. 9 S., R. 20 E., quarter corner between secs. 27 and 28 ; iron post....... 1, 048.408

T. 9 S., R. 20 E., quarter corner between secs. 28 and 29 , cross corner, in telephone post; two 40 -penny nails........................... 065.24

T. 9 S., R. 20 E., center of sec. 29,10 feet from corner fence post, 18 inches above ground, in brace of corner fence post; 40-penny nail.......... 1, 103. 72

\section{EASTON 15' (OSKALOOSA 30') QUADRANGLE.}

[Latitude, $39^{\circ} 15^{\prime}-39^{\circ} 30^{\prime}$; longitude, $95^{\circ}-95^{\circ} 15^{\prime}$.]

From point near Boling north to point near Hund.

Boling, near, in old ravine near where road crosses creek bed of west fork of Little Stranger Creek; stone marked "U. S. 913".

Lansing, 5 miles west of, at intersection of roads, northeast corner of sec. 24, T. 9 S., R. 21 E., 50 feet west of bridge 92 , south side of road; iron pipe with brass cap stamped " 972 ".

T. 9 S., R. 22 E., northwest corner of sec. 18, at crossroads near High Prairie schoolhouse, on limestone; chiseled square marked " 1075 "............ 1, 074. 20

T. 9 S., R. 22 E., quarter corner on west side of sec. 7, south side of Compton road; marked " 1066 ".

T. 8 S., R. 22 E., southwest corner of sec. 31 , at intersection of roads in Possum Hollow, in stone; aluminum tablet marked " 924 "

924.690

From Hund west along Union Pacific R. R. to point 7 miles west of Easton.

T. 8 S., R. 21 E., near quarter corner on east side of sec. 13, on Union Pacific R. R., at road crossing; pole marked "U. S. 873"..................

Pleasant Ridge, southwest corner of box-car station, in platform; 40-penny nail..................................................... 1,049. 75

Easton, main crossing; top of rail............................ 903.1

Easton, intersection of Riley Street and main north-south road; on southwest corner of H. Boyle's place; iron post stamped " 904 ".

Easton, in stone step of Methodist Episcopal Church, 0.3 mile west of intersection of Riley Street with main north-south road, at end of Riley Street; aluminum tablet stamped " 909 ".

T. 8 S., R. 20 E., quarter corner between secs. 18 and 19; iron post...... 1, 170.645 


\section{From Pleasant Ridge northeast to Oak Mills.}

T. 8 S., R. 21 E., center of sec. 3, intersection of roads, in center of road, in limestone section corner at northeast corner of Squire's place; aluminum tablet stamped "1098." (Bench mark has been disturbed).

T. 7 S., R. 21 E., center of sec. 34, west side of road on piece of limestone; chiseled square marked " 1086 ".

T. 7 S., R. 21 E., quarter corner between secs. 23 and 24, northwest corner of Joe Adams's place, southeast corner of intersecting roads; iron post stamped "1008".

Oak Mills, in John Davitz's front yard, 19 feet below his store and 2 feet inside of his tight board fence; iron pipe set 4 feet in ground, cap terminating in round knob taken as bench mark, stamped "Missouri River Commission P. B. M. No. 264-82-1"

From Oak Mills west and south to Easton.

Oak Mills, 1.5 miles south and 1.5 miles west of, on half-section road at corner of Henry Paseway's place; large granite bowlder marked "U. S. 1028 "

Oak Mills, 1.5 miles south and 3.5 miles west of, at crossroads, quarter corner on east side of sec. 21 , R. 21 E., T. 7 S.; iron post stamped " 1054 ".. 1, 053.399

T. 7 S., R. 21 E., center of sec. 21 , at intersection of roads; stone marked "U. S. 1054".

Potter, 2 miles east of, southeast corner of NE. $\frac{1}{4}$ sec. 19, T. 7 S., R. 21 E., at crossroads; iron pipe stamped " 1008 "....................... 1,006.967

Easton, 3.5 miles north of, on west side of main pike, in front of Henry Seute's farm; center of large stone marked " 997 "

996.61

Easton, 3 miles north of, 0.25 mile east of Melwood, at fork in road, near Max Blecher's mail box; iron post stamped " 924 ".

923.577

Easton, 1.5 miles north of, on bridge 158, northeast corner of, on railing; nail with white square, marked " 906 "

905.70

From Easton south to point 1.5 miles south of Springdale.

Easton, 1 mile south of, southeast corner of bridge 179; bolt painted "U. S. 887 "

Springdale, 4 miles north of, at W. A. Hastey's place; southwest corner of front-door step, marked "U. S. 923 ".

Easton, 3.3 miles south of, at base of telegraph pole; highest point on rock, painted " 940 "

Easton, 4.6 miles south of, west of road, northwest of white house on east side of road, in root of tree; 40 -penny nail.......................

Springdale, on main east-west road, in front of John McQuillan's residence, on north side of road; iron pipe stamped " 1048 ".

Springdale, 1.5 miles south of, forks in road, northeast corner of Ezra Martz's place; stone marked "U. S. 979"

From Springdale west 5.5 miles, thence north to point 1 mile north of Cummings, thence east and north to point near Parnell.

Springdale, 1 mile west of, in brace of corner fence post; 40-penny nail.... 1,055.85

T. 9 S., R. 20 E., corner of secs. $14,15,22$, and 23 , in corner fence post; 40 penny nail

Edmunds Church corner, 50 feet from corner fence post, in root of elm tree 7 inches in diameter; 40-penny nail............................... 063

T. 9 S., R. 20 E., 35 feet north and 15 feet east of quarter corner between secs. 18 and 19 , on east side of north-south road; iron post stamped "Prim. Trav. Sta. No. 7, 1906". 
T. 9 S., R. 20 E., quarter corner between secs. 7 and 18

T. 9 S., R. 20 E., quarter corner between secs. 6 and 7, at crossroads, in corner fence post; 40-penny nail. ......................... 1,011. 32

Tps. 8 and 9 S., R. 20 E., quarter corner between secs. 6 and 31 ; iron post. . 1, 089.435

Tps. 8 and 9 S., Rs. 19 and 20 E., corner of secs. 1, 6, 31, and 36, at crossroads; top of corner stone............................. 099.54

T. 8 S., Rs. 19 and 20 E., corner of secs. 25, 30,31, and 36; top of corner stone. 1, 122.74

T. 8 S., Rs. 19 and 20 E., quarter corner between secs. 30 and 25, in telephone post; three 40 -penny nails. . . . . . . . . . . . . . . . . . . . 091.58

T. 8 S., R. 20 E., center of sec. 30 , at crossroads, in telephone post; three

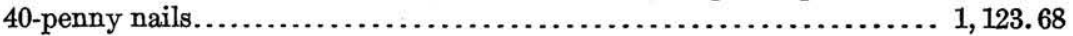

T. 8 S., R. 20 E., quarter corner between secs. 18 and 19; iron post........ 1, 170.645

T. 8 S., R. 20 E., quarter corner between secs. 6 and 7, at crossroads, in telephone post; two 40 -penny nails. . . . . . . . . . . . . . . $124.55 \ldots \ldots \ldots \ldots . \ldots \ldots$

Corpus Christi Church, 0.5 mile west of, at crossroads, in corner fence post;

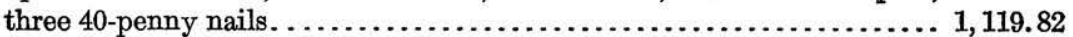

Corpus Christi Church, 1 mile west of, Tps. 7 and 8 S., Rs. 19 and 20 E.; iron post stamped "Prim. Trav. Sta. No. 9, 1906" .................. 1,091.538

T. 7 S., Rs. 19 and 20 E., quarter corner between secs. 30 and 25 , at crossroads, in corner fence post; four 40-penny nails.................. 1, 128.34

T. 7 S., Rs. 19 and $20 \mathrm{E}$., corner of secs. 19, 30, 24, and 25, T corner, in root of 8-inch locust tree; 40 -penny nail......................... 1, 045.32

T. 7 S., Rs. 19 and 20 E., corner of secs. 13, 18, 19, and 24, on southeast corner of east abutment of iron bridge; painted square.

T. 7 S., R. 19 E., quarter corner between secs. 13 and 24 , on east side of north-south road, 10 feet from corner fence post; iron post.

991. 168

T. 7 S., R. 19 E., quarter corner between secs. 12 and 13, in west root of tree; 40-penny nail

T. 7 S., R. 19 E., center of sec. 12 , in corner fence post at northwest corner of crossing; two 40-penny nails.

T. 7 S., R. 19 E., quarter corner between secs. 1 and 12, T corner, in telephone post near E. W. Kaufman's general store; three 40-penny nails...

Cummings, 1 mile north of Tps. 6 and 7 S., R. 19 E., quarter corner between secs. 1 and 36 , in yard of house at end of $\mathrm{T}$ road; iron post........... 1,063.106

Tps. 6 and 7 S., Rs. 19 and 20 E., township corner; top of section corner

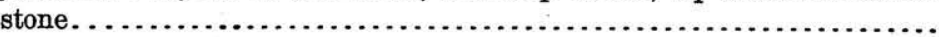

Hawthorne, opposite station, in telephone pole east of tracks; three 40 penny nails

984.53

Bridge 13, northwest abutment of; painted square

Bridge 12, southwest abutment of; painted square $\ldots \ldots \ldots \ldots \ldots \ldots \ldots \ldots 1,009.98$

From sec. 19, T. 7 S., R. 21 E., west to Potter, thence northwest along Atchison, Topeka \& Santa Fe Ry. to Hawthorne.

Potter, 1.8 miles east of, south of road; cross on stone. . . . . . . . . . . . .

Potter, in front of station; top of rail. . . . . . . . . . . . . . . . . . . . . . .

982.24

Mount Pleasant, northwest corner of station; top of rail.

Mount Pleasant, 2 miles northwest of, at railroad culvert 5; top of south rail.

945.5 


\section{ATCHISON 30' QUADRANGLE.}

[Latitude, $39^{\circ} 30^{\prime}-40^{\circ}$; longitude, $95^{\circ}-95^{\circ} 30^{\prime}$.]

From Parnell northeast along Atchison, Topeka \& Santa Fe Ry. to Atchison, thence south along Missouri Paciflc Ry. to p. b. m. 267, Missourl River Commission.

Feet.

Parnell, 35 feet west of general store and post office; iron post.......... 1, 053.82

Bridge 10, Atchison, Topeka \& Santa Fe Ry., northwest corner of north

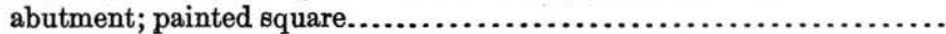

Bridge 9, northwest corner of north abutment; painted square.............

Bridge 8, north side of east abutment; painted square..................

Parnell, 3 miles north of, near railroad crossing; iron post................

Bridge 7, north end of east abutment; painted square..................

Bridge 6, north end of east abutment; painted square..................

Bridge 5, Atchison, Topeka \& Santa Fe Ry., west abutment; painted square...................................................

Bridge 106, Missouri Pacific Ry., west end of north abutment; painted

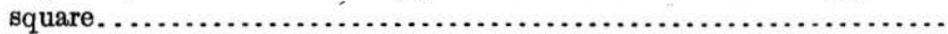

Atchison, 3 miles below Union Station, 130 feet below milepost 327, on side of track near bluff, 59 feet from center of track, 10 feet above grade, 16 feet toward river from wagon road, and 8 feet southeast of 10-inch crab-apple tree; copper bolt in regulation bench-mark stone 18 by 18 inches by 4 inches thick, 3.5 feet underground. Over and concentric with copper bolt is set an iron b. m. pipe 4 feet long with a cap at top terminating in a rounded $\mathrm{knob}$, which is also taken as a permanent bench mark. The top surface of flat stone is marked "B. M."; copper bolt................

Top of cap.

954. 13

929. 11

906. 77

907. 079

871.15

859. 95

849. 31

789.990

795. 701

799. 762

Garden, Lakin, Syracuse, and Tribune quadrangles.

FINNEY, GRANT, HAMLTON, KEARNEX, AND STANTON COUNTIES.

The elevations in the following list are approximate and are based on the bronze tablet marked " 2832 ," in the southwest corner of the courthouse at Garden, the accepted elevation of which is 2,832.034 feet above mean sea level. The initial height from which this bench mark is established is the top of the rail on the main track of the Atchison, Topeka \& Santa $\mathrm{Fe}$ Ry., in front of the telegraph office at Garden, using the railroad company's elevation, 2,829 feet.

The leveling in this area was done by J. C. Barber in 1896, M. C. McFarlane in 1897, and F. C. French in 1898.

\section{GARDEN QUADRATGLE.}

[Latitude, $37^{\circ} 30^{\prime}-38^{\circ}$; longitude, $100^{\circ} 30^{\prime}-101^{\circ}$.]

From Garden along Atchison, Topeka \& Santa Fe Ry. to sec. 7, T. 24 S., R. 33 W.

Garden, on Atchison, Topeka \& Santa Fe Ry., in front of telegraph office; Feet. top of rail............................................2, 829

Garden, southwest corner of courthouse; copper plate stamped "G. C. 2832" 2, 832. 034

Garden, First National Bank, southwest side of main entrance; bronze tablet stamped " G. C. 2830 "'................................. 2, 830. 185

T. $24 \mathrm{~S}$., R. $33 \mathrm{~W}$., on north-south line through center of sec. 15, 48 feet south of Atchison, Topeka \& Santa Fe Ry. track, between Garden and Sherlock; iron post stamped "G. C. 2853"'........................ 2,853. 022

T. 24 S., R. 33 W., 450 feet north and 70 feet west of east quarter corner of sec. 7, south side of Atchison, Topeka \& Santa Fe Ry. track; iron post stamped "G. C. 2870 ". 


\section{LAKIN QUADRANGLE.}

[Latitude, $37^{\circ} 30^{\prime}-38^{\circ}$; longitude, $101^{\circ}-101^{\circ} 30^{\prime}$.]

Bench marks established near public-land corners.

T. 29 S., R. 37 W., southwest corner of sec. 18; iron post stamped "G. C. Feet.

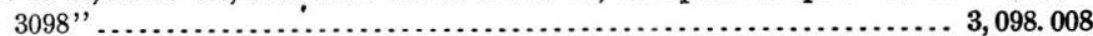

T. 29 S., R. 37 W., southeast corner of sec. 13; iron post stamped "G. C. 2978 "................................................ 2, 977.752

T. 29 S., R. 36 W., southeast corner of sec. 16; iron post stamped "G. C.

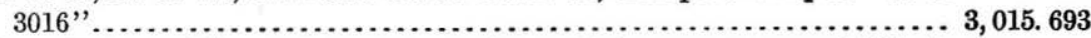

T. 29 S., R. 36 W., southeast corner of sec. 13; iron post stamped "G. C. 3023 "..................................................... 3,022. 951

T. 29 S., R. 35 W., southeast corner of sec. 16 ; iron post stamped "G. C. 3010 "................................................. 3,010.008

T. 29 S., R. 35 W., southeast corner of sec. 13; iron post stamped "G. C. 3020 "................................................... 3,020. 262

T. 28 S., R. 38 W., southeast corner of sec. 36 ; iron post stamped "G. C.

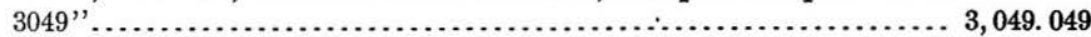

T. 28 S., R. 38 W., southeast corner of sec. 33 ; iron post stamped "G. C. 3106 "'............................................... 3, 106. 486

T. 28 S., R. 37 W., southeast corner of sec. 9 ; iron post stamped "G. C. 3053 "............................................... 3, 053.185

T. 28 S., R. 37 W., southeast corner of sec. 29 ; iron post stamped "G. C.

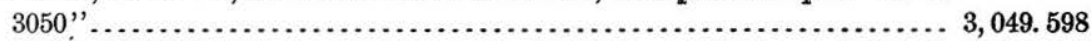

T. 28 S., R. 36 W., southwest corner of sec. 34 ; iron post stamped "G. C. 3048 "'............................................. 3, 047.667

T. 28 S., R. 36 W., southwest corner of sec. 31 ; iron post stamped "G. C. 3059 "............................................. 3,059. 232

T. 28 S., R. 35 W., southwest corner of sec. 34 ; iron post stamped "G. C. 3020 "'............................................... 3,020.412

T. 28 S., R. 35 W., southwest corner of sec. 31; iron post stamped "G. C. 3048 "............................................... 3, 047.640

T. 28 S., R. 34 W., southwest corner of sec. 34 ; iron post stamped "G. C. 2999 ".............................................. 2, 999. 367

T. 28 S., R. 34 W., southwest corner of sec. 31 ; iron post stamped "G. C. 3007 "'............................................. 3,006. 790

T. 27 S., R. 38 W., southeast corner of sec. 33 ; iron post stamped "G. C. 3092 ".............................................. 3,091. 805

T. 27 S., R. 38 W., southeast corner of sec. 36 ; iron post stamped "G. C. 3078 "'.............................................. 3,078. 245

T. 27 S., R. 37 W., southeast corner of sec. 16; iron post stamped "G. C. 3055 "'............................................... 3,054. 867

T. 27 S., R. 37 W., southeast corner of sec. 33; iron post stamped "G. C. 3060 "'................................................ 3,060. 400

T. 27 S., R. 36 W., southwest corner of sec. 34; iron post stamped "G. C. 3094 "'................................................ 3,093.825

T. 27 S., R. 36 W., southwest corner of sec. 31 ; iron post stamped "G. C. 3016 "'............................................. 3,016. 146

T. 27 S., R. 35 W., southwest corner of sec. 34; iron post stamped "G. C. 3076 "'.............................................. 3,076. 041

T. 27 S., R. 35 W., southwest corner of sec. 31; iron post stamped "G. C. 3119 "'............................................ 3, 118.557

T. 27 S., R. 34 W., southwest corner of sec. 34; iron post stamped “G. C. 3074 ".

$$
31826^{\circ}-14-2
$$


T. 27 S., R. 34 W., southwest corner of sec. 31; iron post stamped "G. C. Feet. 3054 ".................................................. 3, 054.285

T. 26 S., R. 38 W., southeast corner of sec. 36 ; iron post stamped "G. C. 3089 "................................................. 3, 089.083

T. 26 S., R. 38 W., southeast corner of sec. 33; iron post stamped "G. C.

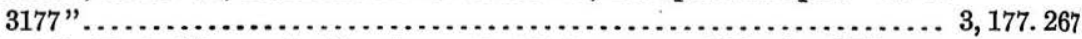

T. 26 S., R. 37 W., south side of sec. 16, 120 feet west of Hartland-Ulysses wagon road; iron post stamped "G. C. 3048"

3, 048. 417 .

T. 26 S., R. 37 W., southeast corner of sec. 33 ; iron post stamped "G. C.

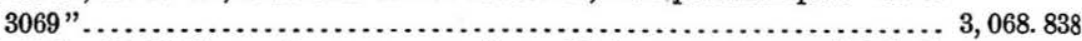

T. 26 S., R. 36 W., southwest corner of sec. 33; iron post stamped "G. C. 3084 "................................................ 3, 083.716

T. 26 S., R. 36 W., southwest corner of sec. 31; iron post stamped "G. C.

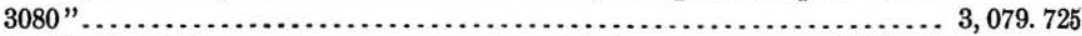

T. 26 S., R. 35 W., southwest corner of sec. 34; iron post stamped "G. C.

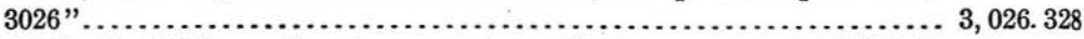

T. 26 S., R. 35 W., southwest corner of sec. 31; iron post stamped "G. C. 3098 ".............................................. 3, 097.876

T. 26 S., R. 34 W., southwest corner of sec. 34; iron post stamped "G. C. 2990 "................................................. 2, 990. 128

T. 26 S., R. 34 W., 620 feet east of southwest corner of sec. 31 ; iron post stamped "G. C. 3010 "..................................... 3, 009. 998

T. 25 S., R. 34 W., northwest corner of sec. 6 ; iron post stamped "G: C.

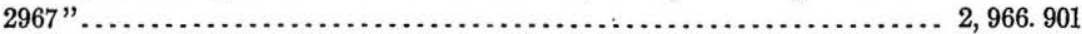

T. 25 S., R. 35 W., northwest corner of sec. 3 ; iron post stamped "G. C.

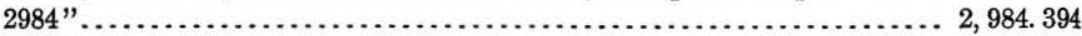

T. 25 S., R. 35 W., northwest corner of sec. 6; iron post stamped "G. C. 2975 "............................................. 2, 975.357

T. 25 S., R. 37 W., near south side of township, west side of HartlandUlysses wagon road; iron post stamped "G. C. 3039 ".............. 3, 038. 718

T. 25 S., R. 36 W., 40 feet southeast of northwest corner of sec. 2; iron post stamped "G. C. 2990 " ................................... 2, 989.798

T. $25 \mathrm{~S}$., R. 38 W., 650 feet west of east side of sec. 3, south of Atchison, Topeka \& Santa Fe Ry. track; iron post stamped "G. C. 3112"........ 3, 112.044

T. 25 S., R. 37 W., line between secs. 7 and 8, north of Atchison, Topeka \& Santa Fe Ry. track; iron post stamped "G. C. 3063"............... 3, 063.102

T. 25 S., R. 37 W., 600 feet north of southeast corner of sec. 10, north of Atchison, Topeka \& Santa Fe Ry. track; iron post stamped "G. C. 3040".. 3, 039.891

T. 25 S., R. 36 W., 1,050 feet south of northwest corner; iron post stamped "G. C. $3013 "$.

T. 24 S., R. 36 W., 60 feet east of line between secs. 26 and 27; south side of Atchison, Topeka \& Santa Fẻ Ry. track; iron post stamped "G. C. 2991 "............................................... 2, 990.914

T. 24 S., R. 35 W., 6 feet west of line between secs. 17 and 18, south of Atchison, Topeka \& Santa Fe Ry. track; iron post stamped "G. C. 2969". 2, 968. 966

Deerfield, 2,200 feet west of station; 6 feet west of line between secs. 10 and 11, T. 24 S., R. 35 W., south side of Atchison, Topeka \& Santa Fe Ry. track; iron post stamped "G. C. 2940 " .................... 2, 940. 104

T. 24 S., R. 34 W., 1,417 feet south of east quarter corner of sec. 6 , south of Atchison, Topeka \& Santa Fe Ry. track; iron post stamped "G. C. 2908". 2, 908.059

T. 24 S., R. 34 W., 1,100 feet south and slightly west of east quarter corner of sec. 3, south of Atchison, Topeka \& Santa Fe Ry. track; iron post stamped "G. C. 2892 ".

T. 24 S., R. 36 W., southeast corner of sec. 3; iron post stamped "G. C. 3125 " 3, 125.493 
T. 24 S., R. 37 W., northeast corner of sec. 21 ; iron post stamped "G. C. Feet. 3244 "..................................................... 3, 243.950

T. 24 S., R. 38 W., southeast corner of sec. 13; iron post stamped "G. C.

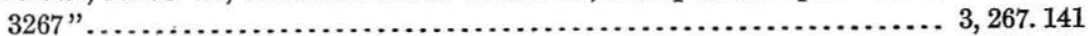

Hartland, 0.5 mile west of ; iron post stamped "G. C. 3040 "........... 3, 039.891

T. 24 S., R. 37 W., near quarter corner on west side of sec. 34 , triangulation station; iron post stamped "G. C. 3249 " ......................... 3, 248. 939

\section{SYRACUSE QUADRANGLE.}

[Latitude, $37^{\circ} 30^{\prime}-38^{\circ}$; longitude, $101^{\circ} 30^{\prime}-102^{\circ}$.]

Bench marks established near public-land corners.

T. 29 S., R. 38 W., southwest corner of sec. 18; iron post stamped "G. C.

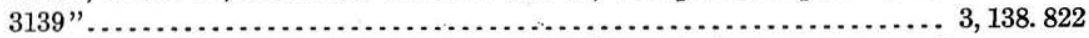

T. 28 S., R. 41 W., quarter corner east side of sec 33 ; iron post stamped

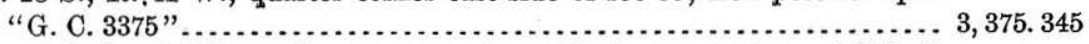

T. 28 S., R. 42 W., southeast corner of sec. 36 ; iron post stamped "G. C.

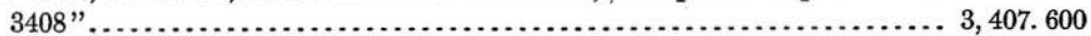

T. 28 S., R. 42 W., southeast corner of sec. 33 ; iron post stamped "G. C.

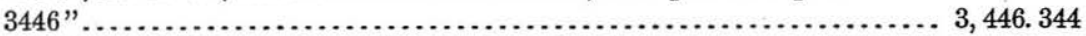

T. 28 S., R. 41 W., southeast cörner of sec. 36 ; iron post stamped "G. C.

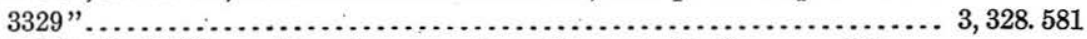

T. 28 S., R. 41 W., southwest corner of sec. 13; east side Syracuse-Johnson wagon road; iron post stamped "G. C. 3341 ".................... 3, 341. 298

T. 28 S., R. 40 W., southeast corner of sec. 36 ; iron post stamped "G. C. 3222 "................................................ 3, 222. 096

T. 28 S., R. 40 W., southeast corner of sec. 33 ; iron post stamped "G. C. 3276 "............................................. 3, 275. 937

T. 28 S., R. 39 W., southeast corner of sec. 36 ; iron post stamped "G. C.

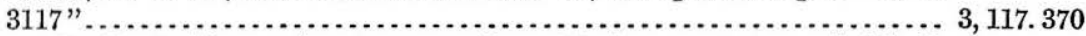

T. 28 S., R. 39 W., southeast corner of sec. 33; iron post stamped "G. C. 3187 "............................................. 3, 186.517

T. 27 S., R. 42 W., southeast corner of sec. 33 ; iron post stamped "G. C.

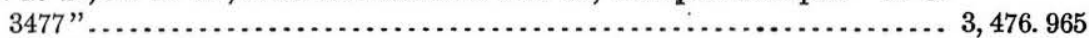

T. 27 S., R. 42 W., southeast corner of sec. 36 ; iron post stamped "G. C.

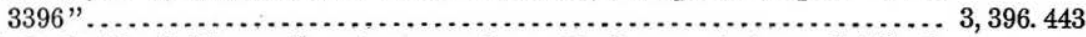

T. 27 S., R. 41 W., southeast corner of sec. 33; iron post stamped "G. C. 3351 "............................................... 3, 351.435

T. 27 S., R. 41 W., southwest corner of sec. 36 ; iron post stamped "G. C.

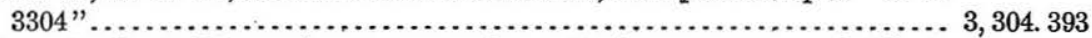

T. 27 S., R. 40 W., southeast corner of sec. 33; iron post stamped "G. C.

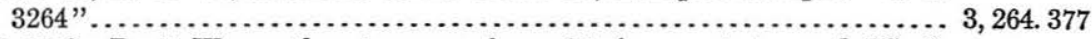

T. 27 S., R. 40 W., southeast corner of sec. 36 ; iron post stamped "G. C. 3193 "............................................... 3, 192.658

T. 27 S., R. 39 W., southeast corner of sec. 33; iron post stamped "G. C.

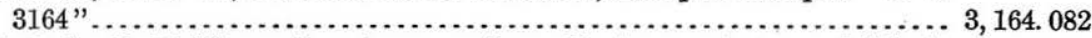

T. 27 S., R. 39 W., southeast corner of sec. 36 ; iron post stamped "G. C.

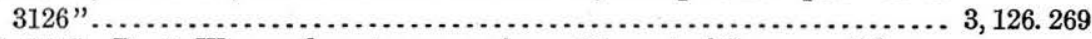

T. 27 S., R. 41 W., southwest corner of sec. 36, east of Syracuse-Johnson wagon road; iron post stamped "G. C. 3304" ...................... 3, 304. 343

T. 27 S., R. 41 W., southwest corner of sec. 13, east of Syracuse-Johnson wagon road; iron post stamped "G. C. 3284"

T. 26 S., R. 39 W., northwest corner of sec. 6 ; iron post stamped "G. C.

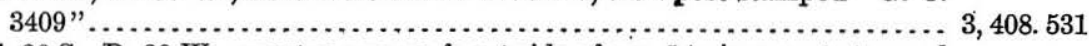

T. 26 S., R. 39 W., quarter corner of east side of sec. 14; iron post stamped

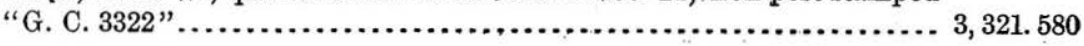


T. 26 S., R. 40 W., northeast corner of sec. 6; iron post stamped "G. C. Feet.

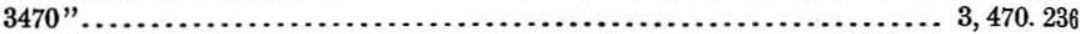

T. 26 S., R. 40 W., northeast corner of sec. 3; iron post stamped "G. C.

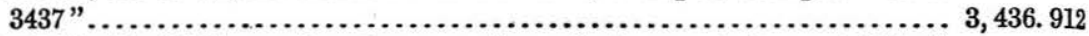

T. 26 S., R. 42 W., northeast corner of sec. 5; iron post stamped "G. C. 3434 "............................................. 3, 433.710

T. 26 S., R. 42 W., northeast corner of sec. 2; iron post stamped "G. C. 3430 ".................................................. 3, 430. 353

T. 26 S., R. 41 W., southwest corner of sec. 36, east of Syracuse-Johnson wagon road; iron post stamped "G. C. 3265 " ..................... 3, 265. 164

T. 26 S., R. 41 W., 30 feet west and 30 feet south of northeast corner of sec. 23, on wagon road from Syracuse to Johnson; iron post stamped "G. C.

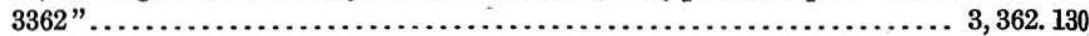

T. 25 S., R. 38 W., southwest corner of sec. 31 ; iron post stamped "G. C.

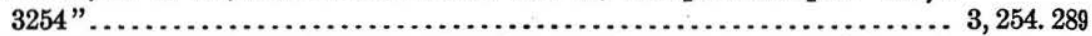

T. 25 S., R. 39 W., northeast corner of sec. 4; iron post stamped "G. C.

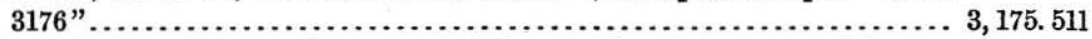

T. 25 S., R. 39 W., southeast corner of sec. 3 ; iron post stamped "G. C.

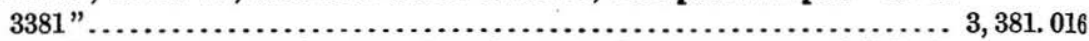

T. 25 S., R. 41 W., southeast corner of sec. 33; iron post stamped "G. C.

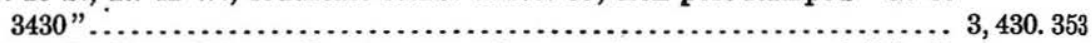

T. 25 S., R. 42 W., northeast corner of sec. 4; iron post stamped "G. C. 3489 "............................................... 3, 489.429

T. 25 S., R. 42 W., southeast corner of sec. 16; iron post stamped "G. C.

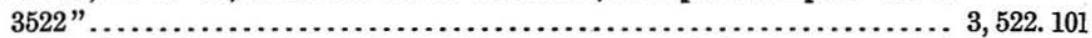

T. 25 S., R. 41 W., 30 feet west of Johnson wagon road; iron post stamped "G. C. 3392".

Syracuse, about 8 miles south of, triangulation station on west side of Johnson road; iron post stamped "G. C. 3508" ..................... 3, 507.505

T. 25 S., R. 40 W., southwest corner of sec. 31; iron post stamped "G. C.

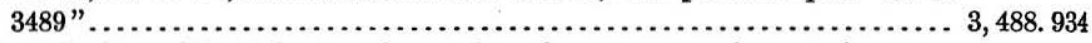

T. 25 S., R. 38 W., 70 feet southeast of northwest corner of sec. 6 ; iron post stamped "G. C. 3147 "................................ 3, 146. 576

T. 24 S., R. 41 W., near center of sec. 2 ; iron post stamped “G. C. 3247 ”.. 3, 246.611

T. 24 S., R. 42 W., southeast corner of sec. 36 ; iron post stamped "G. C. 3435 "................................................ 3, 435. 419

T. 24 S., R. 42 W., east side of sec. 1, at fence corner 50 feet south of Arkansas River; iron post stamped "G. C. 3267 " .................... 3, 266.986

T. 24 S., R. 41 W., 10 feet east of fence between secs. 3 and 4, 47 feet south of Atchison, Topeka \& Santa Fe Ry. track; iron post stamped "G. C. 3254 ".

T. 24 S., R. 40 W., 1,765 feet south and 30 feet east from northwest corner of sec. 7, 47.5 feet south of Atchison, Topeka \& Santa Fe Ry. tracks;

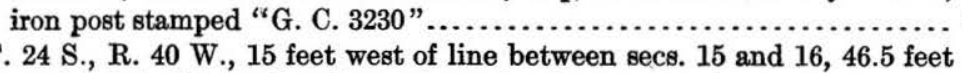
south of Atchison, Topeka \& Santa Fe Ry. tracks; iron post stamped "G. C. 3198 "................................................ 3, 198.401

T. 24 S., R. 39 W., 15 feet east and 10 feet south of northwest corner of sec. 19, 46 feet south of Atchison, Topeka \& Santa Fe Ry. tracks; iron post

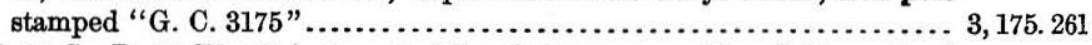

T. 24 S., R. 39 W., 12 feet west of line between secs. 22 and 21 , south of Atchison, Topeka \& Santa Fe Ry. track; iron post stamped “G. C. 3152" . 3, 152.234

T. 24 S., R. 38 W., 150 feet east of west side of sec. 30, north of Atchison, Topeka \& Santa Fe Ry. tracks; iron post stamped “G. C. 3123 ”..... 3, 122.988 
TRIBUITE QUADRATGLE.

[Latitude, $38^{\circ}-38^{\circ} 30^{\prime}$; longitude, $101^{\circ} 30^{\prime}-102^{\circ}$.]

Bench marks established near public-land corners.

T. 23 S., R. 42 W., 12 feet east of fence betwèen secs. 31 and 36, 47 feet south of Atchison, Topeka \& Santa Fe Ry. tracks; iron post stamped “G. C. 3278 ".......................................... 3, 277. 882

T. 23 S., R. 42 W., 1,848 feet south of northwest corner of sec. 27,48 feet south of Atchison, Topeka \& Santa Fe Ry. tracks; iron post stamped "G. C. 3303 ". $3,302.939$

T. 23 S., R. 42 W., 12 feet east of west side of sec. 19, 48 feet south of Atchison, Topeka \& Santa Fe Ry. tracks, 1.8 miles east of Coolidge; iron post stamped "G. C. 3337".

T. 23 S., R. 43 W., 423 feet south of northwest corner of sec. 22,48 feet south of Atchison, Topeka \& Santa Fe Ry. tracks; iron post stamped "G. C. $3353 "$

\section{Hiawatha quadrangle.}

BROWN COUNTY.

The elevations in the following list were determined by primary leveling extended from precise leveling of the Missouri River Commission and accord with the 1912 adjustment.

The leveling was done in 1913 by R. R. Monbeck.

\section{HIAWATHA QUADRATGLE.}

[Latitude, $39^{\circ} 30^{\prime}-40^{\circ}$; longitude, $95^{\circ} 30^{\prime}-96^{\circ}$.]

From point near Preston, Nebr., west along State line road to polnt near Salem, Nobr. (partly in Nebraska).

Preston, 2.5 miles south by 1 mile west of, northwest corner of T road north; copper nail in base of telephone pole, painted "U. S. T. B. M. 938 "....

Preston, 2.5 miles south by 2 miles west of, northwest corner of $T$ road north; copper nail in base of hedge post, painted "U. S. T. B. M. 973"........

Preston, 2.5 miles south by 2.5 miles west of; on State line; top of rail of Missouri Pacific Ry

Preston, 2.5 miles south by 3.3 miles west of, north side of State line road at $T$ road south, beside telephone pole; copper nail in hedge post, painted "U. S. T. B. M. 940".

Feet.

937. 50

971.79

893.8

939.71

Falls City, 4 miles south of, 800 feet west of $T$ road north, 30 feet south of State line road, at Fred Zorn's residence, in base of limestone hitching post; bronze tablet stamped "1027 Prim. Trav. Sta. No. 21, Nebr., 1913". 1, 025.978

Falls City, 4 miles south by 1 mile west of, at $T$ road north, 50 feet south of State line road; chiseled cross on base of stone hitching post.

Falls City, 4 miles south by 2 miles west of, 140 feet west of T road north, 20 feet south of State line road; copper nail in root of elm tree.........

Falls City, 4 miles south by 3 miles west of, 500 feet west of $T$ road north, 150 feet southwest of William Boothe's residence, 30 feet north of State line road, in base of stone gatepost; bronze tablet stamped "999 Prim. Trav. Sta. No. 20, Nebr., 1913"............................

Falls City, 4 miles south by 4 miles west of, northeast corner of $T$ road north; copper nail in base of telephone pole........................ 1,053.71

Salem, 5 miles south by 1.5 miles east of, at T road south, 10 feet north of State line road; copper nail in base of telephone pole.............. 1, 054.75 


\title{
APPENDIX A.
}

\section{ELEVATIONS ADJUSTED BY THE COAST AND GEODETIC SURVEY FROM PRECISE LEVELING.}

\begin{abstract}
Abilene, Anthony, Atchison, Caldwell, Cheney, Cheyenne Wells, Clay Center, Concordia, Ellis, Ellsworth, Hays, Hill, Hoxie, Hutchinson, Junction City, Kansas City, Kingman, Lawrence, Leavenworth, Mankato, Minneapolis, Oakley, Olathe, Oskaloosa, Russell, Russell Springs, Salina, Sharon Springs, Topeka, and Wamega quadrangles.
\end{abstract}

ATCHISON, CLAY, CLOUD, DICKINSON, DONIPHAN, DOUGLAS, ELLIS, ELLSWORTH, GEARY, GOVE, HARPER, JEFFERSON, JEWELL, JOHNSON, KINGMAN, LEAVEN. worth, logan, mepherson, otta wa, Potta Watomie, reno, republic, RILEY, RUSSELL, SALINE, SHA WEE, SHERIDAN, SUMNER, TREGO, AND WALLACE COUNTIES.

The following descriptions and elevations are taken from reports of the Coast and Geodetic Survey and are republished by permission of the superintendent of that bureau. The bench marks were established by the Coast and Geodetic Survey, and by the Missouri River Commission from precise leveling, and were included in the 1912 adjustment by the Coast and Geodetic Survey. The elevations are likely to be changed only slightly by any future adjustment.

\footnotetext{
ABILENE QUADRANGLE.

[Latitude, $38^{\circ} 30^{\prime}-39^{\circ}$; longitude, $97^{\circ}-97^{\circ} 30^{\prime}$.]
}

From point near Chapman westerly along Union Paciflc R. R. and Atchison, Topeka \& Santa Fe Ry. to New Cambria.

Chapman, 0.5 mile east of, in top of west stone abutment to iron railroad bridge over Chapman Creek, south of track, on offset on which end of iron superstructure rests; bottom of square cut, lettered "U. S. $\square$ B. M." (C. \& G. S. b. m. Z) ..................................... 1, 106.967

Chapman, at east entrance in front or south side of county high school, in top of second stone step above ground, near its west end; bottom of square cut, lettered "U. S. $\square$ B. M." (C. \& G. S. b. m. A 1)................ 1, 118.495

Abilene, in stone doorsill to west entrance to courthouse, on upper surface and near north end of sill; bottom of square cut, marked "U. S. $\square$ B.M." (C. \& G. S. b. m. B 1)

Solomon, in face of dressed-stone wrater table of rough-stone railway station, on west end of building between two windows, about center of outer face of fourth stone from southwest corner of building; intersection of cross cut, marked "U. S. + B. M." (C. \& G. S. b. m. C 1) ............... 1, 175. 743

From Solomon east along Atchison, Topeka \& Santa Fe Ry. to Abllene.

Solomon, in small park in front of station, 4.6 meters south of track; top of limestone post, marked "U. S. $\square$ B. M." (C. \& G. S. b. m. W 2) .... 1, 167.747

Solomon, in east brick wall of Masonic lodge building on north side of Main Street, in fourteenth course above foundation, in seventh brick from southeast corner; copper bolt (C. \& G. S. b. m. X 2)............ 1, 172.330 
Abilene, on south side of east abutment of wagon bridge over Mud Creek, 0.5 mile west of Union Pacific R. R. station, 5.5 feet from bridge; copper bolt in sandstone coping (C. \& G. S. b. m. Z 2)................... 1, 157.412

Abilene, in northwest angle made by crossing of Strong City branch of Atchison, Topeka \& Santa Fe Ry. and Union Pacific R. R., 11.5 meters from Union Pacific track and 10.2 meters from Atchison, Topeka \& Santa Fe track; top of limestone post, marked "U. S. $\square$ B. M.". (C. \& G. S.

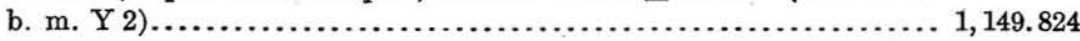

\section{ANTHONY QUADRANGLE.}

[Latitude, $37^{\circ}-37^{\circ} 30^{\prime}$; longitude, $98^{\circ}-98^{\circ} 30^{\prime}$.]

From point near Basil southerly along Atchison, Topeka \& Santa Fe Ry. to Anthony.

Basil, 29 paces west of center of side track, on property of N. J. Blake, in line with front line of his porch, 0.7 meter from northeast corner; bottom of square hole in top of limestone post, marked "U. S. $\square$ B. M." (C. \& G. S. b. m. Z 4) ...................................... 1, 598.940

Rago, 34 paces southeast of intersection of Englewood and Hutchinson \& Southern branches of Atchison, Topeka \& Santa Fe Ry., 18 paces directly south of Englewood branch, on northwest corner of property of Dave Stratton; bottom of square hole in top of limestone post, marked "U.S. $\square$ B. M." (C. \& G. S. b. m. A 5)........................ 1, 446.756

Duquoin, about 30 feet north of station, and 44 paces directly west of Atchison, Topeka \& Santa Fe tracks, 3.18 meters northeast of northeast corner of Mr. Maxwell's general store; bottom of square hole in top of limestone post, marked "U. S. $\square$ B. M." (C. \& G. S. b. m. B 5)...... 1, 584.013

Harper, in west face of building on northeast corner of Central Avenue and Main Street, controlled by Attorney Nashburn and occupied as a barber shop by M. E. Parker and as an implement store by Clarence Rogers, in sixteenth course of bricks above foundation and on third brick from north side of window in southwest corner of building; copper bolt (C. \& G. S. b. m. C 5)..................................... 1,421.677

Ascot, on right of way, between switch and main track, 7.1 meters west of center of main track and 7.2 meters east of center of switch, in line with station sign at Ascot; bottom of square hole in top of limestone post, marked "U. S. $\square$ B. M." (C. \& G. S. b. m. D 5) ................... 1, 419.744

Anthony, 1 kilometer northwest of Anthony Southeast Base, along line of base and about 150 paces east of railroad tracks; bottom of square hole in top of limestone post, marked "U. S. $\square$ B. M." (C. \& G. S. b. m. E 5).. 1, 385.139

Anthony, 1.1 miles north of schoolhouse, at triangulation station Anthony Southeast Base, 89 meters east of Springfield Avenue, on north side of road, on property of $R$. R. Beam; bronze station mark in top of limestone block bedded in concrete (C. \& G. S. b. m. Anthony S. E. B. A)..... 1,376.453

Anthony and Harper, about equally distant from, at triangulation station Anthony Northwest Base, on land belonging to W. W. Millican of Thorntown, Ind.; bronze station mark in top of limestone block embedded in concrete (C. \& G. S. b. m. Anthony N. W. B. A) ................ 1, 395. 168

Anthony, on property of Poorman Milling Co., 3 paces north of their office, 21 paces from middle of road east of their office; bottom of square hole in top of limestone post, marked "U. S. $\square$ B. M."' (C. \& G. S. b. m.

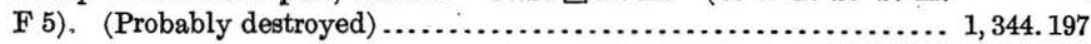




\section{ATCFISON 30' QUADRANGLE.}

[Latitude, $39^{\circ} 30^{\prime}-40^{\circ}$; longitude, $95^{\circ}-95^{\circ} 30^{\prime}$.]

From point 5.5 miles below Atchison northerly near Missouri River to Atchison.

Atchison, 5.5 miles below, 30 feet below lower end of iron bridge across Walnut Creek, on bluff side of track, 68 feet from center and 45 feet north of t. b. m. 541; copper bolt in bench-mark stone (U. S. C. E. p. b. m.

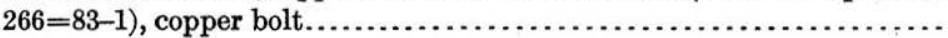
Cap on pipe

Feet. 784. 155 788. 181

Atchison, 4.25 miles below, 242 feet below milepost 326 , 742 feet below south end of railroad bridge 103, on bluff side of track, 14 feet from center and 15 feet east of wagon road; highest point in square cut on em-

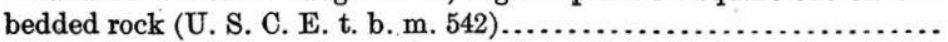

Atchison, 3 miles below, at prominent point, 130 feet below milepost 327, on bluff side of track, 59 feet from center, 10 feet above grade, 16 feet toward river from wagon road, 8 feet southeast of 10-inch crab-apple tree; copper bolt in bench-mark stone (U. S. C. E. p. b. m. 267), copper

bolt......................................................

Cap on pipe.

795.701

799.762

Atchison, 3 miles below, 985 feet above railroad bridge 104 over small creek, 108 feet below milepost 327, on bluff side of track, 15 feet from center; highest point in square cut on rock, marked "U $\square$ S" (U. S. C. E.t. b. m. $543)$

Atchison, 1.8 miles below station, 1,900 feet below bridge 106 over creek, just below ice house, on west side of track, 35 feet from center; horizontal furrow in copper bolt in natural ledge (U. S. C. E. p. b. m. $268=$ old

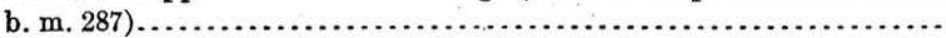

Atchison, on west side of Gillespie Street, 710 feet south of its intersection with Park Street, at foot of bluff, 35 feet west of bank of White Clay Creek; copper bolt in natural ledge about 4 feet below surface of ground and surmounted by an iron pipe (U. S. C. E. p. b. m. 269=84-1), copper bolt.......................................................

Cap on pipe

Atchison, on Miller's Hotel, at southeast corner of Third and Commercial streets, on Commercial Street side, 15 inches back from Third Street side; highest point in square cut in water table, marked "U $\square \mathrm{S}$ " (U.S.

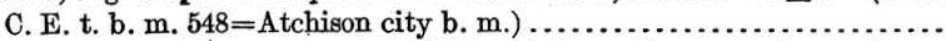

Atchison, at northwest corner of Fifth and Santa Fe streets, in southwest corner of tower at south entrance of First Presbyterian Church; copper bolt in second course of stone from ground (U. S. C. E. p. b. m. 270)....

Atchison, on northeast corner of Fifth and Santa Fe streets, 1 foot east of east building line; highest point in square cut in curbstone, marked " $U \square \mathrm{S}$ "

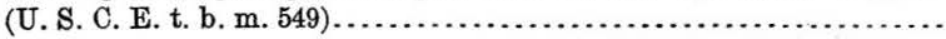

Atchison, on northeast corner of west abutment of Atchison Bridge; highest point in square formed on southwest angle of cross, thus $亡$ (U. S. C. E.

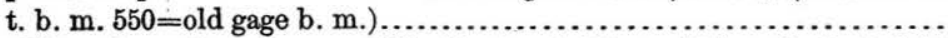

Atchison, in southeast corner of Burlington \& Missouri River R. R. freight station, 41 inches west from corner and 2 inches from south face of water

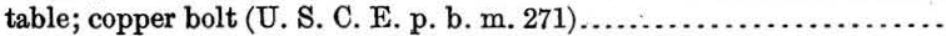

Atchison, in north end of east abutment of Atchison Bridge across Missouri River, in top course of masonry, northwest corner, 5 inches from either bevel edge of stone; copper bolt (U. S. C. E. p. b. m. 272)............ 


\section{CALDWELL QUADRANGLE.}

[Latitude, $37^{\circ}-37^{\circ} 30^{\prime}$; longitude, $97^{\circ} 30^{\prime}-98^{\circ}$.]

At Spring.

Spring, 6 feet north of telegraph pole at station sign, on right of way of Atchison, Topeka \& Santa Fe Ry.; bottom of square hole in top of limestone post, marked "U. S. $\square$ B. M." (C. \& G. S. b. m. G 5)

\section{CHENEY QUADRANGLE.}

[Latitude, $37^{\circ} 30^{\prime}-38^{\circ}$; longitude, $97^{\circ} 30^{\prime}-98^{\circ}$.]

From point near Darlow southerly along Atchison, Topeka \& Santa Fe Ry. to point near Pretty Prairie.

Darlow, on right of way, 7.2 meters south of mail crane, 2.6 meters west of center of main track, 5.6 meters south of south wall of general store of Mrs. Ottir Umstat; bottom of square hole in top of limestone post, marked “U. S. $\square$ B. M." (C. \& G. S. b. m. Q 4) ........................... 1, 556. 745

Castleton, on right of way of railway, 5.7 meters east of center of main track, 2 meters north of north face of railroad station; bottom of square hole in top of limestone post, marked "U. S. $\square$ B. M." (C. \& G. S. b. m.

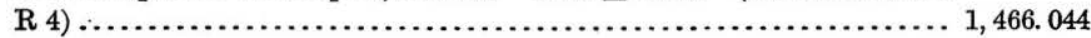

\section{CHEYENNE WELLS QUADRANGLE.}

[Latitude, $38^{\circ} 30^{\prime}-39^{\circ}$; longitude, $102^{\circ}-102^{\circ} 30^{\prime}$.]

On Kansas-Colorado State line.

Kansas-Colorado State line, north of track on railway right of way, at intersection of two lines cut in upper surface of pedestal to iron monument marking line, between round hole and southwest corner; surface of iron, marked "U. S. $\square$ B. M." (C. \& G. S. b. m. U 2).................. 3, 876. 016

\section{CLAY CENTER QUADRANGLE.}

[Latitude, $39^{\circ}-39^{\circ} 30^{\prime}$; longitude, $97^{\circ}-97^{\circ} 30^{\prime}$.]

\section{From point near Talmage northerly along Atchison, Topeka \& Santa Fe Ry. to point} near Sulphur Springs.

Talmage, south of station, 70.2 meters south of north end of curve No. 73 , 2.05 meters east of track; top of limestone post, marked "U.S. $\square$ B.M." (C. \& G. S. b. m. A 3) ................................... 1, 211. 254

Manchester, in town of, in southwest corner stone of abandoned foundation of pumping station, now (1899) used as a cellar, 0.25 meter from west and 0.075 meter from south face of stone; bottom of square cut (C. \& G. S. b. m. B 3) .......................................... 1,294. 708

Longford, in foundation of building belonging to Salina Cement \& Plaster Co., 0.21 meter north of doorway to boiler room and 0.34 meter below woodwork; copper bolt (C. \& G. S. b. m. C 3) ..................... 1, 314.712

Oak Hill, on right of way, between station and Santa Fe Hotel, in group of three trees and 1.2 meters from central one; top of limestone post, marked "U. S. $\square$ B. M." (C. \& G. S. b. m. D 3)........................ 1, 269. 102

Catlin, in largest stone in southwest corner of stone house owned by J. W. Catlin, near south end of trestle 33 over Chapman Creek, 0.21 meter from corner and on west face of building; copper bolt (C. \& G. S. b. m. E 3).. 1, 327.868

Miltonvale, in northwesternmost of 21 cubical sandstone blocks supporting water tank; bottom of square cut (C. \& G. S. b. m. F 3) ............. 1, 376. 264 


\section{CONCORDIA QUADRANGLE.}

[Latitude, $39^{\circ} 30^{\prime}-40^{\circ}$; longitude, $97^{\circ} 30^{\prime}-98^{\circ}$.]

\section{From point near Huscher northerly along Atchison, Topeka \& Santa Fe Ry. to point near Webber.}

Huscher, east of track and opposite stock yards, 130 meters south of station, 0.3 meter west of east fence marking right of way; top of limestone post, marked “U. S. $\square$ B. M." (C. \& G. S. b. m. I 3) ................. 1, 465.640

Concordia, on limestone block forming north coping of west porch of courthouse; bottom of square cut, marked "U. S. $\square$ B. M." (C. \& G. S. b. m. J 3)

Concordia, southwest end of fourth and top iron step at northwest corner of First National Bank building, surface of raised portion and 0.036 meter from iron casing and 0.12 meter from stonework (C. \& G. S. b. m.

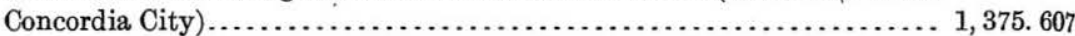

Concordia, on northeast foundation stone of water tank belonging to railroad company, 0.25 mile north of station; bottom of square cut, marked "U. S. $\square$ B. M." (C. \& G. S. b. m. K 3)......................... 1, 367.690

Hannum switch, on capstone of small stone culvert under Missouri Pacific Ry., between second and third telegraph poles southeast of Hannum switch; bottom of square cut, marked "U. S. $\square$ B. M." (C. \& G. S. b. m.

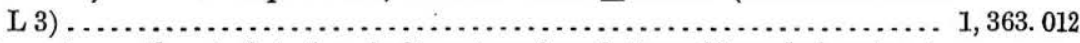

Oneonta, northeast of station, in limestone foundation of barn belonging to Mr. A. C. Nelson, in southwest face of barn, 1.29 meters north of southwest window; copper bolt (C. \& G. S. b. m. M 3) ................. 1, 396.903

Kackley, in stone foundation of elevator leased by A. H. Poage, just southeast of station, on north face and top and eleventh stone from northwest corner; copper bolt (C. \& G. S. b. m. N 3)

Courtland, in southwest angle formed by crossing of Atchison, Topeka \& Santa Fe Ry. with Chicago, Rock Island \& Pacific track, southwest of signal tower, 12.7 meters from Chicago, Rock Island \& Pacific track, 13.9 meters from Santa $\mathrm{Fe}$ on right of way of former; top of limestone post, marked "U. S. $\square$ B. M." (C. \& G. S. b. m. O 3) ................. 1, 500. 611

Lovewell, 2 feet west of shed just west of station, 3 meters south of north siding; top of limestone post, marked "U.S. $\square$ B. M." (C. \& G. S. b. m.

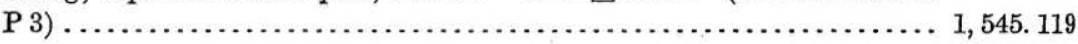

\section{ELIIS QUADRANGLE.}

[Latitude, $38^{\circ} 30^{\prime}-39^{\circ}$; longitude, $99^{\circ} 30^{\prime}-100^{\circ}$.]

From point near Ellis westerly along Union Paciflc R. R. to point near Wakeeney.

Ellis, in east side of stone building used as a railroad station and hotel, in third course above sidewalk and in second stone to left (south) of door; copper bolt (C. \& G. S. b. m. Z 1) ............................. 2, 123.624

Ellis, in front face of west side wall to one-story stone business building owned and occupied by Thomas Daly, in second course above foundation and about center of stone forming course; copper bolt (C. \& G. S. b. m. A 2) .......................................... 120.695

Ellis, in front face of east side wall to two-story stone business building owned and occupied by R. McCloud, in second course above foundation and about middle of stone forming course; copper bolt (C. \& G. S. b. m. B 2)

Ogallah, in east front face of two-story stone building, owned by William Baldwin and used as a store and post office, in fourth course above foundation, in stone forming northeast corner; copper bolt (C. \& G. S. b. m. C 2) 


\section{ELISWORTH QUADRANGLE.}

[Latitude, $38^{\circ} 30^{\prime}-39^{\circ}$; longitude, $98^{\circ}-98^{\circ} 30^{\prime}$.]

\section{From Kanopolis westerly along Union Pacific R. R. to point near Dorrance.}

Kanopolis, on southwest corner of Ohio and Kansas avenues, in north wall of three-story brick hotel building, in fifth course above limestone foundation and in second brick from northeast corner of building; copper bolt (C. \& G. S. b. m. L 1) ............................... 1, 585.410

Ellsworth, in stone foundation to courthouse, in front (east) wall, in second course above ground and in third stone from southeast corner of building, 25 centimeters above top of basement window sill (stone); copper bolt (C. \& G. S. b. m. M 1)................................. 1, 540. 341

Ellsworth, in yard of public school, in top of marble slab set in top of concrete pier marking telegraphic longitude station, edge of square hole is about 0.01 meter north of small round hole marking station, and square hole is not cut deep, two sandstone posts project from top of pier some distance above ground, posts are marked "U. S. Coast and Geodetic Survey"; bottom of square cut (C. \& G. S. b. m. N 1).............. 1, 540.010

Ellsworth, small knob cut on root of box-elder tree at south end of iron road bridge over river, east of bridge, between stone abutment and river bank, two iron nails are driven in top of this knob and rods were held on top of north nail, $\mathbf{0 . 4}$ meter above ground; U. S. Geological Survey water-gage bench mark (C. \& G. S. b. m. Water gage b. m.).......... 1, 524. 098

Wilson, in front of two-story stone building (with iron front to first story), owned by J. F. Tampier and used as a general store, building fronts north, faces track, and is opposite railroad station; in top of stone window sill, east of door; bottom of square cut (C. \& G. S. b. m. O 1), lettered “U. S. $\square$ B. M."..................................... 1, 689. 908

Wilson, in iron front to two-story stone building, owned by J. F. Tampier, on column west of west window, between two square projections near bottom of column; intersection of cross cut (C. \& G. S. b. m. P 1). 1, 691, 096

HAYS QUADRANGLE.

[Latitude, $38^{\circ} 30^{\prime}-39^{\circ}$; longitude, $99^{\circ}-99^{\circ} 30^{\prime}$.]

From point near Gorham westerly along Union Paciflc R. R. to point near Ellis.

Gorham, in front (north) face of Union Hotel, a two-story stone building owned by J. W. Ginther, in sixth course above ground and in stone forming northwest corner about middle of its north face; copper bolt (C. \& G. S. b. m. V 1) ...................................... 1, 916.879

Walker, south of railroad track and east of station, in north wall of twostory stone building owned by Catholic Church, in sixth course above ground, in stone forming northwest corner; copper bolt (C. \& G. S. b. m.

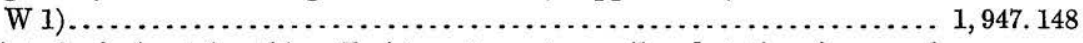

Victoria, in front (north) wall of two-story stone railroad station, in second course above platform, in second stone from northeast corner of building; copper bolt (C. \& G. S. b. m. X 1) .......................... 1, 927. 644

Hays, at southeast corner of First National Bank building, at entrance, on left-hand end of lower step as you enter building, in upper surface of stone; bottom of square cut, lettered "U. S. $\square$ B. M." (C. \& G. S. b. m. Y 1) ............................................ 1,998. 227 


\section{HIIL QUADRANGLE.}

[Latitude, $39^{\circ}-39^{\circ} 30^{\prime}$; longitude, $99^{\circ} 30^{\prime}-100^{\circ}$.]

At Wakeeney.

Wakeeney, in stone doorsill to courthouse, building fronts west and bench mark is at left or north side of door; bottom of square cut, marked “U. S. $\square$ B. M." (C. \& G. S. b. m. D 2).

\section{HOXIE QUADRANGLE.}

[Latitude, $39^{\circ}-39^{\circ} 30^{\prime}$; longitude, $100^{\circ}-100^{\circ} 30^{\prime}$.]

From point near Wakeeney westerly along Union Paciflc R. R. to point near Grinnell.

Collyer, in front (west) face of stone pump house to railroad water tank, in fifth course above ground and in stone forming southwest corner; copper bolt lettered "U. S. O B. M." (C. \& G. S. b. m. E 2)......... 2, 582. 344

Quinter, 500 meters south of railroad, in north wall to two-story brick schoolhouse, in sixth course of brick above stone foundation and in second brick from northeast corner; copper bolt (C. \& G. S.b.m. F 2).. 2 2, 679. 574

Buffalo Park, in east wall of stone pump house at west end of railroad station platform, in second course above platform and in stone forming southeast corner; copper bolt lettered "U. S. O B. M." (C. \& G. S.

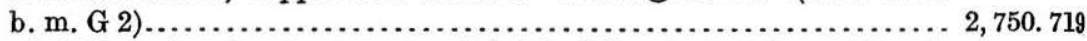

Grainfield, in iron front to two-story brick building (called Opera House), fronts east and mark is near southeast corner; the maker's mark is on iron in raised letters and cross is placed as follows: "Mesker \& Bros. St. +Louis, Mo.", the letters U. S. B. M. were cut in iron immediately below cross (C. \& G. S. b. m. H 2) ............................. 2, 814. 217

HUTCHINSON QUADRANGLE.

[Latitude, $38^{\circ}-38^{\circ} 30^{\prime}$; longitude, $97^{\circ} 30^{\prime}-98^{\circ}$.]

From point near Johnstown southerly along Union Paciflc R. R. and Chicago, Rock Island \& Paciflc Ry. to point near Darlow.

Johnstown, 4 meters directly east of station post, 8.2 meters east of center of railroad track, T. 19, R. 3 W.; bottom of square hole in top of limestone post, marked "U.S. $\square$ B. M." (C. \& G. S. b. m. E 4)............... 1, 392.176

Hilton, on land of Peavey Elevator Co., between office and elevator, 4.7 meters north of north face of elevator, $\cdot 3.3$ meters south of south face of office, 13.7 meters east of center of main track, 4.6 meters east of center of switch, T. 19, R. $3 \mathrm{~W}$.; bottom of square hole in top of limestone post, marked “U. S. $\square$ B. M." (C. \& G. S. b. m. F 4) ................... 1, 518. 491

McPherson, on stone slab at south side of base of standpipe which supplies McPherson with water, 55 paces northwest of waterworks station, 54 paces east of center of main track; T. 19, R. $3 \mathrm{~W}$.; bottom of square hole, marked "U. S. $\square$ B. M." (C. \& G. S. b. m. G 4)................. 1, 495. 804

McPherson, at main doorway on south side of McPherson Opera House, on east end of second stone step from bottom, about 0.3 meter from east stone column supporting archway over entrance; bottom of square hole, marked “U. S. $\square$ B. M." (C. \& G. S. b. m. H 4)................. 1, 496.913

McPherson, 1.5 miles west of, on right of way of Chicago, Rock Island \& Pacific Ry., at junction of that railroad and Missouri Pacific Ry., in southwest corner formed by intersection of two roads, 14 meters from center of Chicago, Rock Island \& Pacific Ry. track and 16 meters from center of Missouri Pacific Ry. track; bottom of square hole in top of limestone post, marked "U. S. $\square$ B. M." (C. \& G. S. b. m. I 4)............. 1, 489.242 
Groveland, on property of Chicago, Rock Island \& Pacific Ry., 1.6 meters south of their elevator office, 27.5 meters east of center of main track, 12.5 meters east of center of siding leading to their office; bottom of square hole in top of limestone post, marked "U. S. $\square$ B. M." (C. \& G. S. b. m.

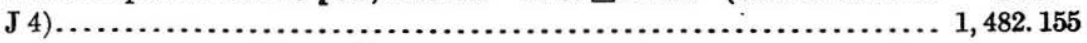

Inman, on property of Henry Vogt, 0.7 meter north of northwest corner of his lumberyard office, 4.3 meters south of hydrant adjacent to office on north side, 250 feet east of main track of railroad, 185 feet east of center of siding; bottom of square hole in top of limestone post, marked "U. S. $\square$ B. M."

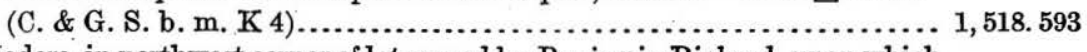

Medora, in northwest corner of lot owned by Benjamin Richard, upon which is a building used as a hotel, largest building in town, 62 paces southeast of southeast corner of railway station and 20 paces north of northwest corner of hotel; bottom of square hole in top of limestone post, marked “U. S. $\square$ B. M." (C. \& G. S. b. m. L 4) ....................... 1, 477.054

Hutchinson, 1 mile east of, on State Reformatory, on north side of southwest pavilion, on sill of second window from northwest corner, 13 centimeters from east side of window and 1.06 meters from west side; bottom of square hole (C. \& G. S. b. m. M 4). $1,534.485$

Hutchinson, at Sherman and Poplar streets, west entrance to First Presbyterian Church, north end of top step, in top of limestone post; bottom of square hole, marked "U. S. $\square$ B. M." (C. \& G. S. b. m. N 4) ...... 1, 532.428

Hutchinson, at Second and Main streets, southwest entrance to Citizens' Bank, on northwest end of top step; bottom of square hole, marked "U. S. M $\square$ B. M." (C. \& G. S. b. m. O 4) ..................... 1, 529. 338

Fernie, a stock siding on (Hutchinson \& Southern) Atchison, Topeka \& Santa Fe Ry., in T. 22, R. 6 W., 4.7 meters south of south fence of stockyard, 13.4 meters east of center of main track; bottom of square hole in top of limestone post, marked "U. S. $\square$ B. M." (C: \& G. S. b. m. P4) .... 1, 548.005

\section{JUNCTION CITY QUADRANGLE.}

[Latitude, $39^{\circ}-39^{\circ} 30^{\prime}$; longitude, $96^{\circ} 30^{\prime}-97^{\circ}$.]

\section{From point near Manhattan southwesterly along Union Paciflc $\mathbf{R}$. $\mathbf{R}$. to point near Chapman.}

Manhattan, iron railroad bridge over Big Blue River, north of track, on step in west abutment on which end of iron superstructure rests, on outer top stone; bottom of square cut, marked "U. S. $\square$ B. M." (C. \& G. S. b. m.

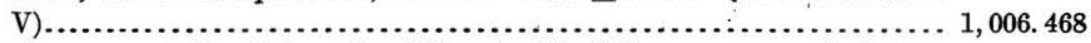

Ogden, on east (front) face of public school building, on east end of stone forming northeast corner, in fifth course above ground; intersection of cross, marked "U. S. + B. M." (C. \& G. S. b. m. W) ............. 1, 058.410

Fort Riley, in smooth surface of water table of stone railroad station, on east end near southeast corner; intersection of cross cut, marked "U. S. + B. M." (C. \& G. S. b. m. X) .................................. 1, 069. 955

Junction City, on east end of railroad station, on eighth stone from northeast corner of building, in first course above brownstone foundation showing above platform, on right of door to express storeroom in this end of station; intersection of cross cut, marked "U. S. + B. M." (C. \& G. S. b. m. Y) ... 1, 080.270 


\section{KANSAS CITY 30' QUADRANGLE.}

[Latitude, $39^{\circ}-39^{\circ} 30^{\prime}$; longitude, $94^{\circ} 30^{\prime}-95^{\circ}$.]

From Kartaas City westerly along Atchison, Topeka \& Santa Fe Ry. to point near Cedar Junction.

Kansas City, 2 miles west of, in top of east abutment to railroad bridge in Johnson County, Kans., about 0.5 mile east of first wagon bridge across Kansas River, above Kansas City, on east abutment, north of track; bottom of square hole cut in stone, lettered "U. S. $\square$ B. M." (C. \& G. S.

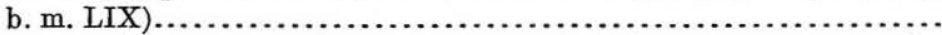

Argentine, in top of stone foundation to one of the iron columns supporting viaduct over railroad yard, short distance west of railroad station, on foundation to first column south of main track on west side of bridge; bottom of square cut, lettered "U. S. $\square$ B. M." (C. \& G. S. b. m. LX)...

Holliday, 0.5 mile east of, near southeast corner of stone culvert under railroad, south of track, in top of coping; bottom of square cut, lettered

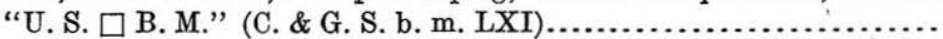

Holliday, 0.5 mile west of, stone pier under east end of iron railroad bridge over Mill Creek, north of track, in top and near northeast corner of pier; bottom of square cut, lettered "U. S. $\square$ B. M." (C. \& G. S. b. m. LXII)

Holliday, 0.5 mile west of, stone pier under west end of iron railroad bridge over Mill Creek, north of track, in top and near north end of pier; bottom of square cut, lettered "U. S. $\square$ B. M." (C. \& G. S. b. m. LXIII)........

Holliday, 1 mile south of, Atchison, Topeka \& Santa Fe Ry. (Emporia branch) bridge over Mill Creek, in top of stone abutment under north end of bridge, east of track, near southeast corner of highest portion of abutment; bottom of square cut, lettered "U. S. $\square$ B. M." (C. \& G. S. b. m. LXIV)

Feet.

748. 69

751. 66 :

760. 21

764.10

764.165

From Kansas City northeasterly near Missourl River to point near Leavenworth Junction.

Kansas City, on southeast corner of James Street and Lyon Avenue, in stone foundation of police station No. 2, on James Street face, $22 \frac{1}{2}$ inches from its northwest corner, in second course of stone from top, 3.5 feet above sidewalk; copper bolt (U. S. C. E. p. b. m. 234)..............

Kansas City, on southeast corner of James Street and Lyon Avenue, in front of police station No. 2, on east side of James Street, 23.5 feet south from northwest corner of sidewalk; highest point in square cut on curbstone,

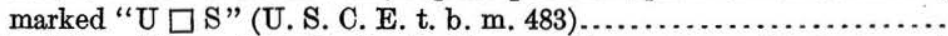

Kaw River, Missouri Pacific Ry. bridge over, in west face of first pier east of west abutment, 7.2 feet south of north corner, in third course of masonry from ground, 2 feet below grade of Missouri Pacific Ry. track; copper bolt (U. S. C. E. p. b. m. 235) .......................................

Kaw River, on left bank of, at third bridge above mouth, over which cable cars cross, on first pier east of west abutment, on west face of pier at northwest corner; highest point in square cut on top of projection of second course of stone above ground, marked "U $\square \mathrm{S}$ " (U. S. C. E. t. b. m. 484).

Kansas City, northeast corner of Third Street and Wyandotte Avenue, on south face next to southwest corner of two-story brick building, on outer edge next to corner-stone pillar of iron doorsill (U. S. C. E. t. b. m. 485,

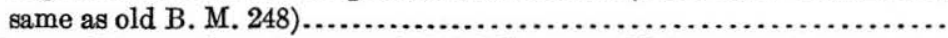

Kansas City, northwest corner of Third Street and Minnesota Avenue; top of north nut in rim of hydrant (U. S. C. E. t. b. m. 486 , is also city b. m.).

753. 040

741. 458

739. 713

777.462

778. 332 
Kansas City, between Missouri Pacific and Kansas City, Wyandotte \& Northwestern R. R. tracks, 460 feet below their crossing, at southeast corner of old gas factory, on top of foundation; highest point in square

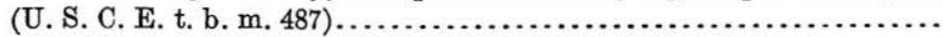

Kansas City, at upper end of, 300 feet below K. T. brick works, opposite headblock of switch, 50 feet east from center of track, near right of way fence; copper bolt in bench-mark stone (U.S. C.E. p. b. m. 236), copper bolt.

Cap on pipe

Feet.

762. 443

Kansas City, west side of Wyandotte and Kansas City water-works pump house, between two windows, 1 foot north of south one, 14 feet south of northwest corner of wall, 4.3 feet above ground; copper bolt (U. S. C. E.

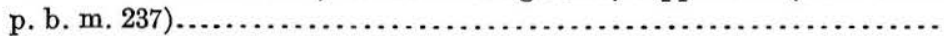

Quindaro, 0.5 mile below old town, 2,295 feet above Kansas City and Wyandotte waterworks pump house, 285 feet below bridge $73 \frac{3}{4}$, on river side of track, 80 feet from center; copper bolt in bench-mark stone (U. S. C. E. p. b. m. 238, same as 74-1), copper bolt...................... Cap on pipe.

Quindaro, 738 feet above old town, 1.25 miles above Kansas City water

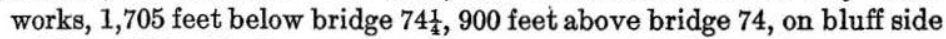
of Missouri Pacific Ry. track, 7 feet from center; highest point in square

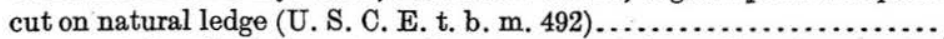

Nearman, 0.5 mile below, 1.8 miles above Quindaro, directly opposite Parkville, 275 feet below road crossing, on line with west side of road running north toward Parkville, 50 feet north of track center; copper bolt in bench-mark stone (U. S. C. E. p. b. m. 239), copper bolt............

Cap on pipe.

Pomeroy, 2.25 miles below, at first small stream, 1,630 feet below water tank, 2,145 feet above road crossing, on southwest corner of east abutment of railroad bridge, a small wagon bridge spans the hollow a little higher up the bluff; copper bolt (U. S. C. E. p. b. m. 240)....................

Pomeroy, 2.25 miles below, on northwest corner of top stone of east abutment of railroad bridge; highest point in square marked " $\mathrm{U} \square \mathrm{S}$ "

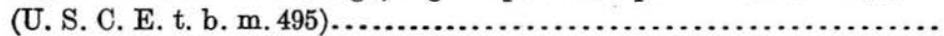

Pomeroy, 1.8 miles below, opposite center of water-tank, 25 feet north from center of track; copper bolt in bench-mark stone (U.S. C. E. p.b. m. 241), copper bolt

Cap on pipe.

Pomeroy, in foundation of F. H. Betton's house, the first residence on west side of street running south from station, in northeast face of foundation under bow window on east end of house, in center of stone in second course of masonry from top; copper bolt (U. S. C. E. p. b. m. 242).....

Pomeroy, 195 feet south of station, in northeast corner of lot owned by I. C. Henderson, 18 feet south of southeast corner of old post-office building, 2 feet from angle of stone wall; copper bolt in bench-mark stone

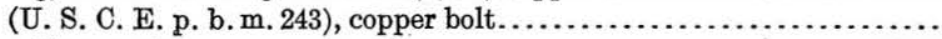
Cap on pipe.

Pomeroy, 0.6 mile above, 960 feet above east end of trestle over Marshall Creek, 125 feet from river, 75 feet south of railroad, 21 feet above grade of same; center of cavity in disintegrated rock ledge from which copper bolt has been extracted (U. S. C. E. p. b. m. 244, same as old b. m. 260)..

Pomeroy, 0.6 mile above, 1,810 feet above milepost 296, 655 feet above end of railroad bridge over Marshall Creek, on bluff side of track, 8 feet from center; highest point in square cut on rock (U. S. C. E. t. b. m. 499)...

749. 349

753. 411

752.177

746. 974

751.012

757. 731

755. 832

759. 890

774. 802

753. 112

757. 157

773.801

753. 643 
Connor, 350 feet east of railroad station, on river side of track, 240 feet from center, in northwest corner of lot owned by Mr. Maxwell, 15 feetnortheast from north corner of Eli Davis's house; copper bolt in bench-mark stone (U. S. C. E. p. b. m. 245, same as 76-1), copper bolt................. Cap on pipe.

Connor, in foundation wall at southeast corner of public schoolhouse, on its east face, 6 inches north from corner and 20 inches above ground; copper bolt (U. S. C. E. p. b. m. 246)

Connor, 2.5 miles above, 1,265 feet below first road crossing below Popes Siding, 1,315 feet below bridge No. 79, over small creek, 220 feet above center of small bridge where Gillman or bottom road turns east away from track (Mr. E. Piper and Mr. Tull live on this road about 0.5 mile east of track), 33 feet west of track center, on line of right of way; copper bolt in bench-mark stone (U. S. C. E. p. b. m. 247), copper bolt............ Cap on pipe

Popes station, 720 feet above milepost 302, 443 feet above Mr. Pope's house, 394 feet above upper head block of siding, on east end of upper abutment of small culvert; highest point in square marked "U $\square \mathrm{S}$ " (U. S. C. E.

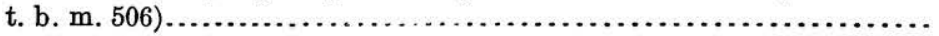

Feet. 754. 421 758. 496

771. 629

\section{KINGMAN QUADRANGLE.}

[Latitude, $37^{\circ}-37^{\circ} 30^{\prime}$; longitude, $98^{\circ}-98^{\circ} 30^{\prime}$.]

From point' near Pretty Prairie southerly along Atchison, Topeka \& Santa Fe Ry. to point near Basil.

Pretty Prairie, at northeast corner of property owned by Peter Kabiel, about 35 paces west of center of main track, 25 paces directly south of Hollingwood's granary; bottom of square hole in top of stone post, marked "U. S. $\square$ B. M." (C. \& G. S. b. m. S 4) .....................

Pretty Prairie, 0.25 mile south by 0.5 mile east of, at intersection of range and section line at northeast corner of sec. 24, T. $26 \mathrm{~S}$., 0.5 mile northwest from triangulation station Pretty Prairie; bottom of square hole in top of stone post, marked "U. S. $\square$ B. M." (C. \& G. S. b. m. T 4)... 1, 578. 448

Varner, on right of way, in line with telegraph poles, 15 meters north of center of public road through Varner, 9.5 meters west of center of main track; bottom of square hole in top of stone post, marked "U. S.

B. M." (C. \& G. S. b. m. U 4).............................. 1, 519.922

Lashmet, on right of way, directly north of station platform, 4 meters west of center of track, 34 meters north of center of public road at Lashmet, 37 paces northeast of northeast corner of house owned by John Lashmet; bottom of square hole in top of limestone post, marked "U. S. $\square$ B. M."

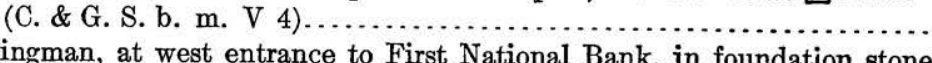
which forms top step, 0.16 meter south of main wall of building, 0.15 meter south of north end of stone step, 0.22 meter east of west edge; bottom of square hole, marked "U. S. $\square$ B. M." (C. \& G. S. b. m. W 4).. 1, 510.142

Kingman, 2.25 miles west by 3.1 miles south of city hall, 35.6 meters northwest of schoolhouse, 350 paces directly east of windmill which marks triangulation station Kingman; bottom of square hole in top of stone post, marked "U. S. $\square$ B. M." (C.\& G. S. b. m. X 4) (A bolt with cross in top is leaded into north side of stone and intersection of cross lines is 0.4427 meter below bench mark)

Carvel, on right of way, 1.15 meters northwest from northwest. face of mill owned by D. N. Barnhill, 16.3 meters southwest from center of main track; bottom of square hole in top of limestone post, marked "U. S. B. M." (C. \& G. S. b. m. Y 4) 
LAWRENCE QUADRANGLE.

[Latitude, $38^{\circ} 30^{\prime}-39^{\circ}$; longitude, $95^{\circ}-95^{\circ} 20^{\prime}$.]

From point 0.5 mile east of Weaver westerly along Atchison, Topeka \& Santa Fe Ry. to Lawrence.

Weaver, 0.5 mile east of, in east abutment to iron railroad bridge 29 , in middle (near west end) of stone forming top of northwest corner of abutment; bottom of square cut, lettered "U. S. $\square$ B. M." (C. \& G. S. b. m. D).

Feet.

Eudora, 0.5 mile west of, in west abutment to iron railroad bridge over Wakarusa Creek, north of track, near middle and east end of stone forming top of northeast corner; bottom of square cut, lettered "U. S.

B. M." (C. \& G. S. b. m. E)

810. 904

Lawrence, in east end of station, near south end of stone sill to door and near front edge, building is of brick, with stone trimmings; bottom of shallow square cut (C. \& G. S. b. m. F).

Lawrence, at entrance of mill race, in top of rounded portion of stone retaining wall on shore side of race; bottom of square cut (C. \& G. S. b. m.

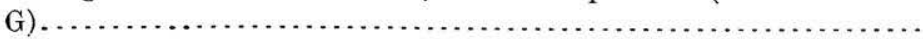

799. 644

LEAVENWORTH 15' QUADRANGLE.

[Latitude, $39^{\circ} 15^{\prime}-39^{\circ} 30^{\prime}$; longitude, $94^{\circ} 45^{\prime}-95^{\circ}$.]

From point 2 miles below Leavenworth Junction northerly along Missouri River to Kickapoo.

Leavenworth Junction, 2 miles below, opposite foot of Spar Island, 970 feet above milepost 303, 1,610 feet above railroad trestle 81 , on second bench of bluff from foot, 120 feet from Missouri Pacific Ry. track; top of copper bolt in bench-mark stone (U. S. C. E. p. b. m. 248=77-1), copper bolt.

799. 283

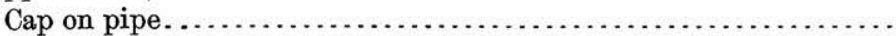

Leavenworth Junction, 93 feet above center of station, 100 feet above head block at junction, 18 feet east of center of track, 29.5 feet above lower head block of siding; copper bolt in bench-mark stone (U. S. C. E. p.

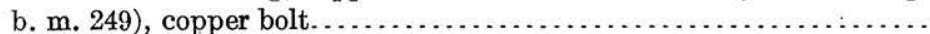

Cap on pipe ..................................................... feet above bridge on bluff side of track; 12.5 feet from center; in flat piece of ledge about 2 feet below grade of track; highest point in square

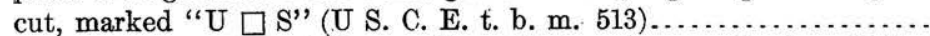

Leavenworth, 1.8 miles below station, 820 feet above coal mine, 39 feet below whistle post, on bluff side Missouri Pacific track, 8 feet from center, at foot of sidehill cut; highest point in square cut on embedded rock and marked "U $\square \mathrm{S}$ " (U. S. C. E. t. b. m. 514)........................ Leavenworth, 1.6 miles below station, on shelf of bluff, opposite East Leavenworth, on lower side of small ravine, 200 feet from river, 20 feet west from center of siding leading to coal mine; copper bolt in bench-mark stone (U. S. C. E. p. b. m. $250=78-1$ ), copper bolt.................

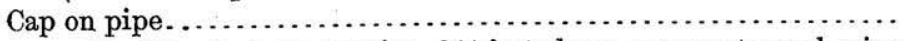
756. 229 760. 294

807. 679

811,744

Leavenworth, 0.8 mile below station, 344 feet above runway to coal mine over tracks, on bluff side of Union Pacific track, 7 feet from center, at foot of sidehill cut; highest point in square cut in well-embedded rock (U. S. C. E. t. b. m. 515) 
Leavenworth, on north side of Great Western Stove Co.'s brick building, one block south of Union Station, 3.4 feet west from northeast corner and 5 feet above ground; copper bolt leaded horizontally (U. S. C. E. p. b. m 251)

Leavenworth, in brick building occupied by Rohlfing Bros., grocers, on southeast corner of Third and Cherokee streets, on west end of stone window sill, Cherokee Street side; copper bolt (U. S. C. E. p. b. m. 252).

Leavenworth, at riverward foot of arch forming main entrance to north side of old Union Station; cross cut in top of water table (U. S. C. E.

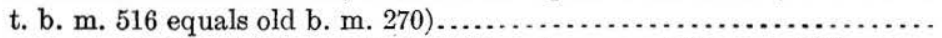

Leavenworth, in retaining wall at northwest corner of Main and Cherokee streets, 59 feet north of south end of wall, 78 feet south of south end of station; in fourth course of masonry above ground; copper bolt (U. S.

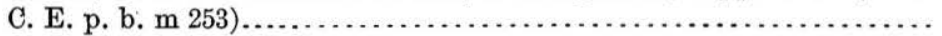

Leavenworth, on east side of Union Station, on south end of doorstep to first door south of main entrance; bighest point in square marked " $\square \square$ "

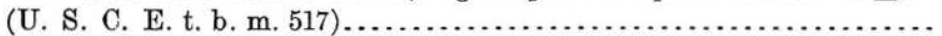

Leavenworth, 0.7 mile above station, 85 feet below milepost 310 , 500 feet above coal mine, 8 feet below head block of switch on bluff side of track, 7 feet from center and on level with grade of same; highest point in square

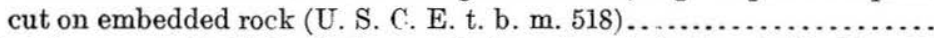

Fort Leavenworth, 30 feet below south face of west abutment of bridge, 27 feet from center of Missouri Pacific Ry. track, 8 feet above grade; copper bolt in bench-mark stone (U. S. C. E. p. b. m. 254 same as 79-1), copper

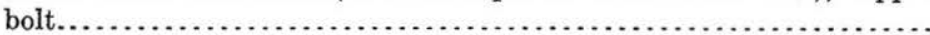

Cap on pipe.

Fort Leavenworth, west abutment of railroad bridge, in south side, 3.5 feet back from east face; in fourth course of masonry above ground at south-

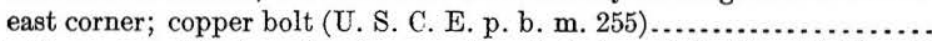

Fort Leavenworth, at southeast corner of west abutment of railroad bridge, 12 feet from center of Missouri Pacific Ry. track on same level; highest point on inclined rock and marked "U $\square$ S" (U. S. C. E. t. b. m. 520)..

Fort Leavenworth, on southeast corner of west abutment of Chicago, Rock Island \& Pacific Ry. bridge, on second course of masonry from ground, 26 inches north of south face; bottom surface of notch cut in top of stone (U. S. C. E. t. b. m. 521 same as gage b. m.)

Fort Leavenworth, at northeast corner of Government stone ice house on river bank, 7 inches west from east face, 5.2 feet above ground; copper bolt (U. S. C. E. p. b. m. 256) .................................

Fort Leavenworth, 0.8 mile above, 1.25 miles above Chicago, Rock Island \& Pacific Ry. bridge across Missouri River, 525 feet below wagon-road crossing, 505 feet below center of bridge across small creek at lower edge of wagon road, 150 feet below point of bluff, on bluff side of track, 28 feet from center; copper bolt in bench-mark stone (U. S. C. E. p. b. m. 257), copper bolt.............................................

Cap on pipe . . . . .

Fort Leavenworth, 2.25 miles above Chicago, Rock Island \& Pacific Ry. bridge, 350 feet above lower head block of Wade siding, on bluff side of track, 2 feet inside of right-of-way fence; copper bolt in bench-mark stone (U. S. C. E. p. b. m. 258 same as 80-1), copper bolt....................

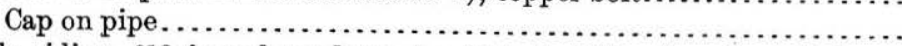

Wade siding, 613 feet above lower head block, 2.25 miles above Chicago, Rock Island \& Pacific Ry. bridge at Forth Leavenworth, 262 feet above p. b. m. 258, on river side of track, 30 feet from center, at top of river bank; highest point in square cut on rock (U. S. C. E. t. b. m. 525)....

Feet.

781. 681

786. 517

768. 945

774. 792

771. 196

778.273

787. 603

791.691

788. 059

781. 659

785. 189

775. 556

772.895

776.960

768. 735

772.813

773. 283 
Kickapoo, 1.8 miles below, 9 feet above upper end of bridge 95 over Salt Creek, on bluff side of Missouri Pacific Ry., 24 feet from center of track; copper bolt in bench-mark stone (U. S. C. E. p. b. m. 259), copper bolt. . Cap on pipe

Kickapoo, 0.25 mile below, 885 feet below trestle, 1,035 feet above milepost 316,85 feet above upper end of small bridge over drain for cut, on bluff side of track, 9.7 feet from center and 2.5 feet above grade; copper bolt leaded horizontally into face of natural ledge (U. S. C. E. p. b. m. 260).

Kickapoo, 912 feet below west end of trestle, on bluff side of track, 7.5 feet from center and 3.5 feet above grade, 10 feet above p. b. m. 260; copper bolt in northwest exposure of cut rock (U. S. C. E. p. b. m. 529 same as old b. m. 278).

Kickapoo, 0.25 mile below, 880 feet below lower end of trestle, 1,035 feet above milepost 316, 100 feet above small bridge, bluff side of track, 10 feet from center, on level with grade; highest point in square cut on

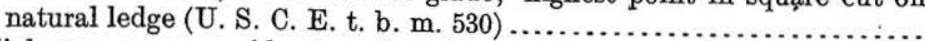

Kickapoo, on upper side of small ravine, 30 feet from vertical bank of small stream, bluff side of track, 80 feet from center, George Sharp's house bears S. $88^{\circ} \mathrm{W}$. (mag.), 130 feet distant; copper bolt in bench-mark stone (U. S. C. E. p. b. m. 261 same as 81-1), copper bolt................... Cap on pipe.

Kickapoo, opposite upper end of bridge 96, Missouri Pacific Ry., bluff side of track, 15 feet from center and 4 feet below grade; highest point in squre cut on natural ledge, letters U. S. cut on vertical face just below bench (U. S. C. E. t. b. m. 531)

Feet.

773. 335

777. 393

794. 037

794. 444

792.571

800.933

804.995

796. 590

\section{MANKATO $30^{\prime}$ QUADRANGLE.}

[Latitude $39^{\circ} 30^{\prime}-40^{\circ}$; longitude $98^{\circ}-98^{\circ} 30^{\prime}$.]

From point near Webber northerly along Atchison, Topeka \& Santa Fe Ry. to point 2 miles south of Superior, Nebr.

Webber, opposite north end of station platform, 8 paces west of siding; top of limestone post, marked "U. S. $\square$ B. M." (C. \& G. S. b. m. Q 3)..... 1, 667.673

Superior, 2 miles south of, on receiving stone of central pier of railroad bridge over Republican River, 0.088 foot east of end pier of second span from north; bottom of square cut, marked "U. S. $\square$ B. M." (C. \& G. S. b. m. R 3) ............................................. 550.227

\section{MINNEAPOLIS QUADRANGLE.}

[Latitude $39^{\circ}-39^{\circ} 30^{\prime}$; longitude $97^{\circ} 30^{\prime}-98^{\circ}$.]

From point near Sulphur Springs northerly along Atchison, Topeka \& Santa Fe Ry. to point near Huscher.

Sulphur Springs, near signpost of flag station, public road crosses track between bench mark and station sign, 14.5 meters north of sign and 4.6 meters east of track; top of limestone post, marked "U. S. $\square$ B. M." (C. \& G. S. b. m. G 3) .................................. 1, 573. 428

Aurora, just south of station, between second and third trees in park of railroad; top of limestone post, marked "U. S. $\square$ B. M." (C. \& G. S. b. m. H 3)............................................. $1,481.555$

\section{OAKIEY QUADRANGLE.}

[Latitude, $39^{\circ}-39^{\circ} 30^{\prime}$; longitude, $100^{\circ} 30^{\prime}-101^{\circ}$.]

From point near Grinnell westerly along Union Paciflc R. R. to point west of Page City.

Grinnell, in east wall of stone pump house to railroad water tank, in ninth course above foundation, in stono forming northeast corner of course; copper bolt (C. \& G. S. b. m. I 2) ........................... 2, 911.123 
Oakley, in east wall of stone pump house to railroad water tank, in third course above ground, in stone forming southeast corner of course; copper bolt, marked "U. S. $\square$ B. M." (C. \& G. S. b. m. J 2) ................. 3, 052.212

Monument, north of railroad and 800 meters east of station, in front (south) wall of stone basement to one-story frame dwelling house, in second course above ground, in stone forming west side of east window; copper bolt, lettered "U. S. $\square$ B. M." (C. \& G. S. b. m. K 2) ............. 3, 172.779

\section{OLATHE QUADRANGLE.}

[Latitude, $38^{\circ} 30^{\prime}-39^{\circ}$; longitude, $94^{\circ} 30^{\prime}-95^{\circ}$.]

From point 0.8 mile east of Cedar Junction westerly along Atchison, Topeka \& Santa Fe Ry. to point 0.5 mile east of Weaver.

Cedar Junction, 0.8 mile east of, on west abutment to iron railroad bridge No. 19 over Cedar Creek, at northeast corner, about center of stone forming top; bottom of square cut, lettered "U. S. $\square$ B. M." (C. \& G.

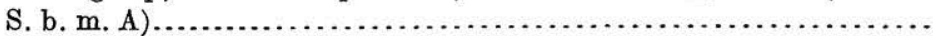

Desoto, 0.25 mile east of, on top of east abutment to iron railroad bridge, near center of stone forming northwest corner; bottom of square cut,

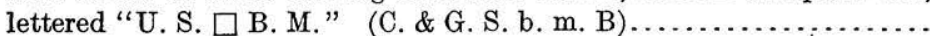

Desoto, three-story brick flour mill owned by J. M. Hadley, in west (front) wall, in second course above stone foundation, in second brick from northwest corner; copper bolt (C. \& G. S. b. m. C) .................

790.084

798. 093

From point near Newington west and north along Kansas City, Clinton \& Springfield Ry. to point north of Olathe.

Newington, 75 meters west of State line where it crosses railroad track, on top of west abutment to bridge over Big Blue Creek, between superstructure and north rail; bottom of square cut in stone, marked "U. S.

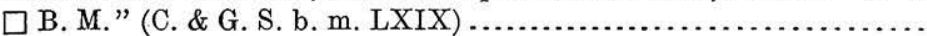

Morse, in yard to residence of N. J. McKitrick, south of house and 5 feet from bay window, nearly opposite east side; top of stone post, marked "U. S. $\square$ B. M." (C. \& G. S. b. m. LXVIII) …................. 1, 094. 128

Olathe, in front (east) wall of Avenue Hotel (three-story brick), hotel is across street west of courthouse, in fourteenth course above stone foundation, in fourth brick from northeast corner; copper bolt (C. \& G. S. b. m.

LXVII) $\ldots \ldots \ldots \ldots \ldots \ldots \ldots \ldots \ldots \ldots \ldots \ldots \ldots \ldots \ldots \ldots \ldots \ldots \ldots \ldots \ldots \ldots \ldots \ldots \ldots \ldots \ldots \ldots \ldots \ldots$
Olathe, on north side of courthouse, under north entrance, just east of stone wall supporting this entrance, in upper surface of stone coping to basement entrance; bottom of square cut, lettered "U. S. C. \& $\square$ G. S. B. M." (C. \& G. S. b. m. LXVI) ............................ 1, 035. 785

Olathe, in northwest corner of courthouse yard, 10 paces from fence on north side and 2 paces from fence on west side; top of marble post, marked “U. S. $\square$ B. M." (C. \& G. S. b. m. LXV) ..................... 1, 030. 461

\section{OSKALOOSA QUADRANGLE.}

[Latitude, $39^{\circ}-39^{\circ} 30^{\prime}$; longitude, $95^{\circ}-95^{\circ} 30^{\prime}$.]

From point 0.5 mile east of Club House westerly along Atchison, Topeka \& Santa Fe Ry. to point 0.5 mile east of Tecumseh.

Club House, 0.5 mile east of, in top of east abutment to iron railroad bridge over Mud Creek, near middle line and west end of stone forming top of northwest corner; bottom of square cut, lettered "U. S. $\square$ B. M." (C. \& G. S. b. m. H)

Lecompton, 0.5 mile east of, in top of west abutment to iron railroad bridge, near middle line and east end of stone forming top of northeast corner; bottom of square cut, lettered "U. S. $\square$ B. M." (C. \& G. S. b. m. I) ... 
Lecompton, 1 mile west of, in top of west abutment to iron railroad bridge No. 47 over Coon Creek, near middle line and east end of stone forming top of southeast corner; bottom of square cut, lettered "U. S. $\square$ B. M." (C. \& G. S. b. m. J)

Feet.

Grover, 1.25 miles east of, in top of west abutment to railroad bridge No. 55, in middle (near east end) of stone forming top of southeast corner; bottom of square hole, lettered "U. S. $\square$ B. M." (C. \& G. S. b. m. K) ....

846. 216

857.459

From point 1.8 miles below Oak Mills northerly near Missouri River to point 5.5 miles below Atchison.

Oak Mills, 1.8 miles below, 70 feet below center of railroad bridge over small creek coming out of valley, on bluff side of track, 3 feet east from wire fence directly opposite south point of bluff; copper bolt in benchmark stone (U. S. C. E. p. b. m. 262), copper bolt..................

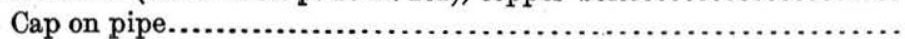

Oak Mills, in northwest side, 8 inches from front face of stone building facing northeast, 65 feet southeast of John Davitz's store, 6 feet above ground; copper bolt (U. S. C. E. p. b. m. 263) ....................

Oak Mills, in John Davitz's front yard, 19 feet below his store, 2 feet inside of tight board fence; copper bolt in bench-mark stone (U. S. C. E. p. b.

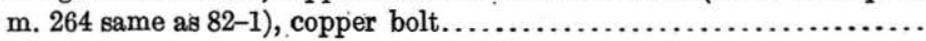

Cap on pipe.

Oak Mills, 2.2 miles above, 0.8 mile above Little Walnut Creek, 180 feet below railroad bridge No. 99, 16 feet toward river from wagon road running parallel to river, near forks in road, on bluff side of track, 65 feet from center; copper bolt in bench-mark stone (U. S. C. E. p. b. m. 265),

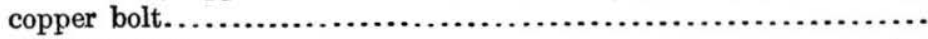

Cap on pipe................................................

Oak Mills, 3 miles above, 413 feet below Joseph Silk's house, 16 feet above whistle post, on bluff side of track, 12 feet from center; highest point in square cut on embedded rock, marked "U $\square$ S" (U. S. C. E. t. b. m. $540)$

RUSSELL QUADRANGLE.

[Latitude, $38^{\circ} 30^{\prime}-39^{\circ}$; longitude, $98^{\circ} 30^{\prime}-99^{\circ}$.]

From point near Dorrance westerly along Union Paciflc R. R. to point near Gorham.

Dorrance, stone foundation under west one of two iron supports under north side of railroad water tank, on top stone north of iron support; bottom

of square hole, marked "U. S. $\square$ B. M." (C. \& G. S. b. m. Q 1) ........
Bunker Hill, in front (east) face of two-story stone Masonic Hall, in third course above stone sidewalk, in second stone from northeast corner of building; intersection of cross cut (C.\& G.S. b. m. R 1), marked "U.S. + B. M.".................................................................. Hill triangulation station; top of post is divided into four sections by two lines cut in top, intersecting at center; bench mark is surface of stone at southwest corner of northeast section (C. \& G. S. b. m. S 1 or

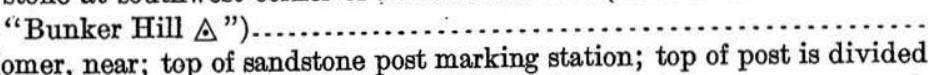

Homer, near; top of sandstone post marking station; top of post is divided
into four sections by two lines cut in top, intersecting at center; bench mark is surface of stone at southwest corner of northeast quarter (C. \& G. S. b. m. T 1 or Russell S. E. Base $\triangle$ ) ........................ 1, 880. 216

Russell, in west end of stone railroad station, at southwest corner of building, in fourth course above platform; intersection of cross cut in stone, marked "U. S. + B. M." (C. \& G. S. b. m. U 1) ................. 1, 833.096 
Russell, 2 miles east of, NW. $\frac{1}{4}$ sec. 25 , T. 13, R. 14, in pasture belonging to Mr. Long; drill hole in top of sandstone post 1.5 feet long by 4 inches square. (G. \& G. S. b. m. "Russell N. W. Base")................ 1,839. 734

\section{RUSSELL SPRINGS QUADRANGLE.}

[Latitude, $38^{\circ} 30^{\prime}-39^{\circ}$; longitude, $101^{\circ}-101^{\circ} 30^{\prime}$.]

From point west of Page City westerly along Union Pacific R. R. to point near Wallace.

Page City, 2.5 kilometers west of, north of track, in upper surface of pedestal to iron monument marking end of bonded portion of Union Pacific Ry., at southeast corner; surface of iron at intersection of cross, marked "U.S. + B. M." (C. \& G. S. b. m. L 2) ...........................

Winona, in upper surface of stone foundation supporting one of iron columns under railroad water tank, in southeast stone of four supporting central group of columns and on its south sloping face; bottom of square cut, lettered "U. S. $\square$ B. M." (C. \& G. S. b. m. M 2)................ 3, 324.990

McAllaster, between railroad track and switch, near southeast corner of platform around railroad station; square cut in top of granite post, marked "U. S. $\square$ B. M." (C. \& G. S. b. m. N 2)................ 3, 155. 617

Turkey Creek, on railway right of way between track and telegraph pole used as the 414 milepost; square cut in top of granite post, marked "U.S.

B. M." (C. \& G. S. b. m. O 2) ............................ 3, 231. 611

\section{SALINA QUADRANGLE.}

[Latitude, $38^{\circ} 30^{\prime}-39^{\circ}$; longitude, $97^{\circ} 30^{\prime}-98^{\circ}$.]

From point near New Cambria westerly along Union Pacific R. R. to Kanopolis.

New Cambria, store and railway station, near west end of stone sill to east door in front of building, which is owned by S. P. Dowmyer; bottom of square cut, marked "U. S. $\square$ B. M." (C. \& G. S. b. m. D 1)........... 1, 199. 860

New Cambria, 0.5 mile west of, iron railroad bridge over Smoky Hill River, west of river, north of track, on top of small stone pier under end of wooden trestlework of bridge; small pier is built on top of larger pier which supports iron bridge; bottom of square cut, marked "U. S.

B. M." (C. \& G. S. b. m. E 1).

$3,227.014$

New Cambria, 1 mile west of, on land owned by Mrs. Mary Marlin, of Salina,

35.05 feet north of second telegraph pole along Union Pacific R. R. west of gate entrance to Marlin's farm, in limestone block 30 inches square and 15 inches high, set in concrete, which marks station at surface; top of copper bolt, lettered "U. S. C. \& G. $18 \bigcirc 96$ Survey" (C. \& G. S. b. m.

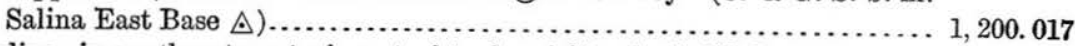

Salina, in northeast part of, east of tanks of Standard Oil Co., 42.75 feet north of line of telegraph poles which parallel on north side the Union Pacific R. R. track, 10 feet east of north-south fence bounding land of Standard Oil Co., in limestone block 30 inches square and 15 inches high, set in concrete, which is surface mark of station; top of copper bolt, lettered "U. S. C. \& G. $18 \bigcirc 96$ Survey"'(C. \& G. S. b. m. Salina West Base $\triangle$ ).

Salina, Missouri Pacific Ry. station, which is constructed of rough stone, under window in west side of bow window in front of building, in face of stone window sill; intersection of two lines forming a cross, marked "U. S. C. \& + G. S. B. M." (C. \& G. S. b. m. F 1)................. 1, 224. 506

Salina, brick building owned and occupied by H. T. Lee Mercantile Co., at left side of steps to main entrance on Santa Fe Street, in upper surface of stone coping to vestibule; bottom of square cut, marked "U. S. B. M." (C. \& G. S. b. m. G 1) 
Salina, brick public-school building on Elm Street, 1 block west of Santa Fe Street, in east wall and near southeast corner of building, in outer face of dressed-stone coping to stone foundation; intersection of two lines forming a cross, lettered "U. S. C. \& + G. S.B.M." (C. \& G. S. b. m. H 1). 1, 225.972

Bavaria, stone railroad station, in outer face of limestone sill to window in east end of building; intersection of cross cut, marked "U. S. + B. M." (C. \& G. S. b. m. I 1).

Brookville, stone public-school building, on east (front) side of building, 1.4 meters from northeast corner, in outer face of limestone coping to foundation; intersection of cross cut, lettered "U. S. + B. M." (C. \& G. S. b. m. J 1)

Terra Cotta switch, 1 mile east of, in upper surface of stone foundation to west one of two iron supports under north side of railroad water tank; bottom of square cut, marked "U. S. $\square$ B. M." (C. \& G. S. b. m. K 1).. 1, 446. 526

From Salina southerly along Union Paciflc R. R. to point near Johnstown.

Mentor, on right of way, 3.5 meters north of station sign, 11.1 meters north of public road, in T. 15, R. 2 W.; bottom of square hole in top of limestone post, marked "U. S. $\square$ B. M." (C. \& G. S. b. m. A 4) ................. 1, 265. 440

Assaria, on right of way, 16.8 meters north of station, 3.8 meters north of first telegraph pole north of station, in line with telegraph poles, 9.3 meters west of railroad, 10 meters east of public road in T. 16, R. 3 W.; bottom of square hole in top of limestone post, marked "U. S. $\square$ B. M." (C. \& G. S. b. m. B 4) ........................................ 1, 282.110

Bridgeport, on right of way, nearly at intersection of north and west platforms of station, 2.8 meters north of north face of station, 5.4 meters east of center of tracks; bottom of square hole in top of limestone post marked “U. S. $\square$ B. M." (C. \& G. S. b. m. C 4) .......................... 1, 301.487

Lindsborg, 25 paces west of railroad, on east face of large three-story brick gristmill, owned by Lindsborg Milling \& Elevator Co. (Inc.), 1.82 meters south of northeast corner of mill, 3.05 meters north of north side of large doorway to mill, on east side; copper bolt (C. \& G. S. b. m. D 4).. 1, 336.126

\section{SHARON SPRINGS QUADRANGLE.}

[Latitude, $38^{\circ} 30^{\prime}-39^{\circ}$; longitude, $101^{\circ} 30^{\prime}-102^{\circ}$.]

From point near Wallace westerly along Union Paciflc R. R. to point near KansasColorado State line.

Wallace, in northeast corner of inclosure east of stone house formerly used as office of division superintendent of Union Pacific R. R., in top of sandstone post forming west support of transit at telegraph longitude station; bottom of square cut, marked "U. S. $\square$ B.M." (C. \& G. S. b. m.P2). 3, 314. 291

Wallace, 3.5 miles west of, in upper surface of stone foundation under one of iron columns supporting railroad water tank, in southwest stone of four supporting central group of columns, near its south side; bottom of square cut, marked "U. S. $\square$ B. M." (C. \& G. S. b. m. Q 2)................... 3, 339. 816

Sharon Springs, in stone foundation under east front wall of one-story business building at, on west side of Main Street and owned by Col. Woodhouse, in stone forming southeast corner of foundation and projects a little outside the stone; copper bolt (C. \& G. S. b. m. R 2).......... 3, 454. 478

Monotony, 10 feet south of station sign, on railway right of way; bottom of square cut in top of granite post, marked "U. S. $\square$ B. M." (C. \& G. S.

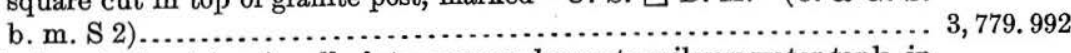

Weskan, in front (east) wall of stone pump house to railway water tank, in second course below top of wooden door casing, in third stone from southeast corner of building; copper bolt (C. \& G. S. b. m. T 2)........ 3, 829. 500 
TOPEKA QUADRANGLE.

[Latitude, $39^{\circ}-39^{\bullet} 30^{\prime}$; longitude, $95^{\circ} 30^{\prime}-96^{\circ}$.]

From point 0.5 mile east of Tecumseh westerly along Atchison, Topeka \& Santa Fe Ry. to Topeka, thence westerly along Union Pacific R. R. to St. Marys.

Tecumseh, 0.5 mile east of, in top of west abutment to iron railroad bridge, north of track, near middle line and east end of stone forming northeast corner of top; bottom of square cut, marked "U. S. $\square$ B. M." (C. \& G. S. b. m. L)

Feet.

865.798

Topeka, repair shops of railway, in upper surface of stone projecting from south wall of paint shop, near southwest corner of building, in slight recess formed hy two offsets from wall running up from stone on which bench mark is cut, one of these offsets forms southwest corner of building;

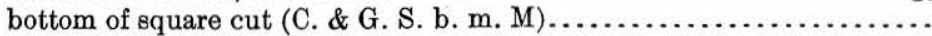

Topeka, in top of stone supporting south end of iron bridge of Atchison, Topeka \& Santa Fe Ry., over Kansas River, east of track, on south side of street which goes under bridge, near northeast corner of stone; bottom of square cut, lettered "U. S. $\square$ B. M." (C. \& G. S. b. m. N)... .......

Topeka, Columbian Building, on Sixth Street between Kansas Avenue and Jackson Street, on west end of stone forming third step above pavement at entrance, close to wall, the surface of stone at south end of cross is bench mark; cross (C. \& G. S. b. m. Jennings).

Topeka, Columbian Building, Sixth Street between Kansas Avenue and Jackson Street, on face of second stone (sandstone) above pavement on west side of entrance, a V-shaped line is nicely cut horizontally across this space, bottom of cut forming this line at its middle point was used as bench mark, and was established by owner of building; lettered " 945

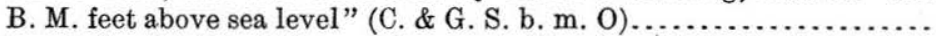

Silver Lake, brick building used as post office (owned by P. H. Butler), south of track, nearly opposite railroad station, on south side of Main Street and on northwest corner of block, middle of stone sill of west window in front (north face) of building, in top of sill; bottom of square

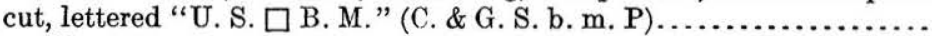

Rossville, 0.25 mile west of, in top of east abutment to iron railroad bridge, north of track and about middle of exposed part of stone supporting end of bridge; bottom of square cut, marked "U. S. $\square$ B. M." (C. \& G. S.

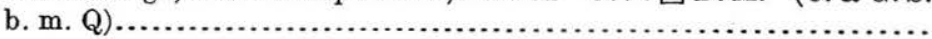

WAMEGO QUADRANGLE.

[Latitude, $39^{\circ}-39^{\circ} 30^{\prime}$; longitude, $96^{\circ}-96^{\circ} 30^{\prime}$.]

From St. Marys westerly along Union Pacifle R. R. to point near Manhattan.

St. Marys, brick building used as an infirmary at St. Mary's College (Jesuit), west face of building, on stone coping of foundation, on third stone from southwest corner, about under center of space between second and third windows from southwest corner; intersection of two lines forming a cross, lettered "U. S. + B. M." (C. \& G. S. b. m. R).....................

Belvue, 2 miles west of, in top of west abutment to iron railroad bridge over Vermilion River, north of track, about center of exposed part of stone supporting end of bridge; bottom of square cut, marked "U.S. $\square$ B. M." (C. \& G. S. b. m. S)

Wamego, at northwest corner of Lincoln A venue and Third Street, two-story stone building owned by Hecker Bros. and used as a dry goods store, in top of stone sill of show window on left of entrance in vestibule at corner (Third Street side); bottom of square cut, marked "U. S. C. \& $\square$ G. S.

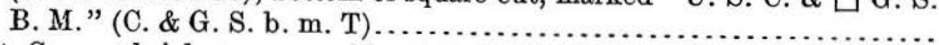

St. George, brick store owned by J. D. Robertson, on stone sill to east window in front (south) end of building; bottom of square cut, lettered "U. S. $\square$ B. M." (C. \& G. S. b. m. U) ........................... 1, 003.400 


\title{
APPENDIX B.
}

\section{ELEVATIONS OF STONE-LINE BENCH MARKS ALONG THE MISSOURI RIVER ESTABLISHED BY THE MISSOURI RIVER COMMISSION FROM PRIMARY LEVELING.}

\author{
Atchison, Dearborn, Leavenworth, and St. Joseph quadrangles. \\ ATCHISON, DONIPHAN, AND LEAVENWORTH COUNTIES.
}

The following descriptions and elevations of bench marks from Fort Leavenworth to St. Cloud, Kans., were taken from the report of the Chief of Engineers, United States Army, for 1891, part 6, pages 3810 and 3811, and are republished by permission of the Chief of Engineers, United States Army. The elevations have been corrected to agree with the 1912 adjustment of the Coast and Geodetic Survey.

The elevations of the stone-line bench marks were determined by the ordinary leveling of the topographic party, running from the adjacent precise-level bench marks. The discrepancy between the precise and ordinary leveling, between successive precise-level bench marks, has averaged about 0.06 foot.

The bench marks were set on lines running across the valley, the lines being usually about 5 miles apart by the river distances, and consist of a flat tile 4 inches thick and 18 inches square, with a copper bolt leaded vertically into the upper face at the center. The tile is set about 3 feet below the surface of the ground and is surmounted with a 4 -inch iron post 4 feet long, upon which an iron cap is bolted.

ATCHISON QUADRANGLE.

[Latitude, $39^{\circ} 30^{\prime}-40^{\circ}$; longitude, $95^{\circ}-95^{\circ} 30^{\prime}$.]

From point 1 mile south of Sugar Lake station north along Missouri River to Palermo.

Doniphan, 2.5 miles below, 1,460 feet above residence of Mrs. Scott, 67 feet west of railroad track, at foot of bluff; copper bolt in tile surmounted by iron pipe (U. S. C. E. b. m. 85-1), copper bolt......................

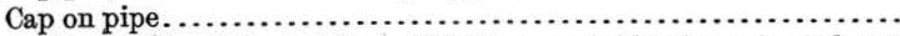

Geary City, 2 miles below, at foot of bluff on west side of wagon road, 155 feet S. $80^{\circ} \mathrm{W}$. (mag.) from schoolhouse, southeast corner of NE. $\frac{1}{4}$ sec. 3 bears N. $851^{\circ} \mathrm{E}$. (mag.), 1,650 feet distant; copper bolt in tile surmounted by iron pipe (U. S. C. E. b. m. 86-1), copper bolt...................

Cap on pipe

Feet.

789.98

793.98

801.50

805.50

Geary City, 2.25 miles along bluff above, near north line of sec. 30, T. 4 S., R. 22 E., 600 feet west of north quarterpost of section, 87 feet northwest of small road bridge at foot of bluff; copper bolt in tile surmounted by

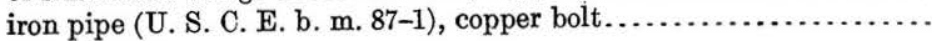

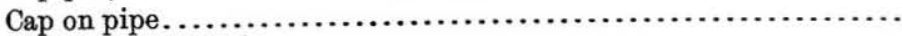

820.19

824. 19 
From point 2.5 miles west of Nodaway north along Missouri River to point near White Cloud.

Mount Vernon landing, at lower point of bluff where it turns up valley, 60 feet from river bank, 500 feet above mouth of Mosquito Creek; copper bolt in tile surmounted by iron pipe (U. S. C. E. b. m. 94-1), copper bolt.

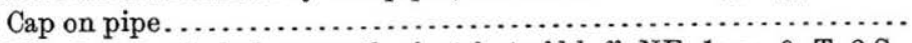

Wolf Creek, 0.8 mile below mouth of, at foot of bluff, NE. $\frac{1}{4}$ sec. 9 , T. $2 \mathrm{~S}$., R. 20 E., approximately 1,000 feet west of east line and 600 feet south of north line of section; copper bolt in tile surmounted by iron pipe (U. S.

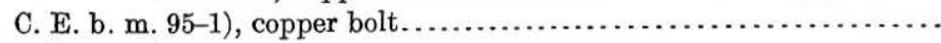

Cap on pipe.

Iowa Point, at northwest corner of Main and Commercial streets; copper bolt in tile surmounted by iron pipe (U. S. C. E. b. m. 96-1), copper bolt.

Cap on pipe.

White Cloud, in northwest corner of dooryard of Charles Osgood, on south side of Main Street, 150 feet west of west line of Second Street; copper bolt in tile surmounted by iron pipe (U. S. C. E. b. m. 97-1), copper bolt.

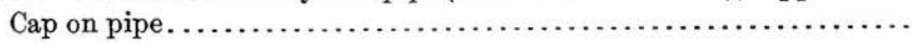

Feet. 844. 76

848.76

839. 34

843.34

853. 93

857.93

883.81

887.81

\section{DEARBORN QUADRANGLE.}

[Latitude, $39^{\circ} 30^{\prime}-39^{\circ} 45^{\prime}$; longitude, $94^{\circ} 45^{\prime}-95^{\circ}$.]

From Palermo northerly along Missouri River to Wathena.

Palermo, 98 feet northeast of house of Dr. Harrington; copper bolt in tile surmounted by iron pipe (U. S. C. E. b. m. 88-1), copper bolt.........

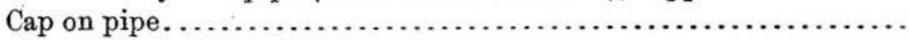

816.02

820.02

\section{LEAVENWORTH QUADRANGLE.}

[Latitude, $39^{\circ} 15^{\prime}-39^{\circ} 30^{\prime}$; longitude, $94^{\circ} 45^{\prime}-95^{\circ}$.]

From point near Fort Leavenworth northerly near Missouri River to Oak Mills.

Fort Leavenworth, 2.5 miles along bluff above Chicago, Rock Island \& Pacific Ry. bridge, at south fence of right of way Missouri Pacific Ry., 350 feet west of headblock of siding; copper bolt in tile surmounted by iron pipe (U. S. C. E. b. m. 80-1), copper bolt.................... Cap on pipe.

Kickapoo Island, 510 feet west of southwest corner of sec. 36, on land owned by Mr. Anderson; copper bolt in tile surmounted by iron pipe

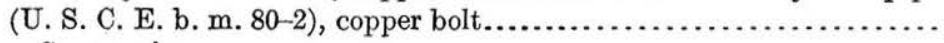
Cap on pipe.

Kickapoo, 40 feet west from small stream in ravine, 86 feet south of Missouri Pacific Ry. trestle bridge; copper bolt in tile surmounted by iron pipe (U. S. C. E. b. m. 81-1), copper bolt......................... Cap on pipe.

ST. JOSEPH QUADRANGLE.

[Latitude, $39^{\circ} 45^{\prime}-40^{\circ}$; longitude, $94^{\circ} 45^{\prime}-95^{\circ}$.]

From Wathena northerly along Missouri River to point near Nodaway.

Wathena, on west line of Bryant Street at intersection with alley south of St. Joseph Street; copper bolt in tile surmounted by iron pipe (U.S.C.E.

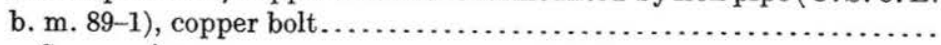
Cap on pipe. 
Wathena, 2.5 miles east of, on right bank, on north side of wagon road, at corner of secs. $25,26,35$, and 36 , T. 3 S., R. 22 E.; copper bolt in tile surmounted by iron pipe (U. S. C. E. b. m. 89-2), copper bolt......... Cạp on pipe.

Belmont, 3 miles above, at foot of bluff, 1,225 feet south of house of Lucas Fedder, near corner of secs. 2, 3, 10, and 11, T. 3 S., R. 22 E.; copper bolt in tile surmounted by iron pipe(U. S. C. E. b. m. 90-1), copper bolt. Cap on pipe.

Cummings landing, on south side of section-line road, 430 feet southeast from house of Nathan Miller, 128 feet west of southeast corner of SW. $\frac{1}{4}$ SE. $\frac{1}{4}$ sec. 21 , T. 2 S., R. 22 E.; copper bolt in tile surmounted by iron pipe (U. S. C. E. b. m. 91-1), copper bolt........................... Cap on pipe............................................

Charleston City, 2 miles below, at foot of bluff, 50 feet east of small ravine, 12 feet in elevation higher than the bottom land, in SW. $\frac{1}{4}$ sec. 24, T. 2 S., R. 21 E.; copper bolt in tile surmounted by iron pipe (U. S. C. E. b. m. 93-1), copper bolt.......................................

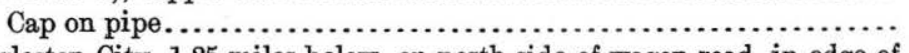

Charleston City, 1.25 miles below, on north side of wagon road, in edge of small orchard, 140 feet southeast of house of E. S. Jenngins, 860 feet west of center of sec. 13, T. 2 S., R. 21 E.; copper bolt in tile surmounted by iron pipe (U. S. C. E. b. m. 93-2), copper bolt....................

Cap on pipe........................................... 



\section{INDEX.}

A.

Abilene quadrangle..

Ackerland.

Allen County.

Anthony

Anthony quadrangle.

Argentine.

Ascot.

Assaria

Atchison

Atchison County

Atchison quadrangle.

Atchison, Topeka \& Santa Fe Ry.... 12, 15, 16, 18, $20,21,22,23,25,26,29,30,32,33,35,36,40$

Atkins County ........................... 11

Atkinson, S. K., work of .................. 11

Aurora.

B.

Barber, J. C., work of.

Basil.

Bavaria

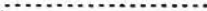

Belmont

Belvue.

Bench mark, description of plate showing

Boling

Bourbon County

Bridgeport.

Brookville...

Brown County

Buffalo Park.

Bunker Hill

Burlington \& Missouri River R. R

Buxton.

\section{C.}

Caldwell quadrangle.

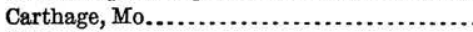
Carvel.

Cedar Junction................................ 30,36

Chapman................................. 22

Charleston City............................ 43

Cheney quadrangle......................... 25

Cherokee County ............................

Chetopa................................ 8,9

Cheyenne Wells quadrangle................. 25

Chicago, Rock Island \& Pacific Ry.. 26, 28, 29, 34, 42

Clay Center quadrangle.

Clay County..

Cloud County.

Coffeyville.

Collyer.

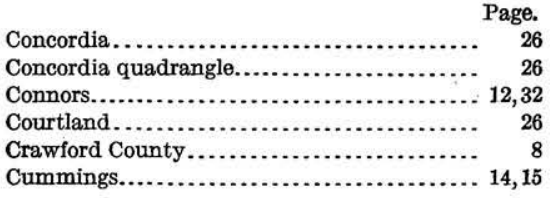

D.

Darlow.................................. 25, 28

Datum, determination of................... $\quad 6$

Dearborn quadrangle........................ 42

Deerfield................................... 18

Deering...................................... 10,11

Desoto.................................. 36

Dickinson County............................ 22

Doniphan.................................. 41

Doniphan County........................... 22,41

Dorrance................................ 27,37

Douglas County.................................. 22

Douglas, E. M., work of ................... 5

Duquoin................................. 23

E.

Easton..................................... 13,14

Easton quadrangle.......................... 13

Elk City................................ 11

Ellis........................................ 26

Ellis County ............................ 22

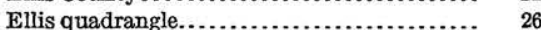

Ellsworth.................................. 27

Ellsworth County ........................... 22

Ellsworth quadrangle..................... 27

Erie...................................... 9

F.

Falls City.................................. 21

Fawn..... 11

Fernie........................................ 29

Finney County............................. 16

Fort Leavenworth..................... 34,42

Fort Riley ............................. 29

French, F. C., work of.................... 16

G.

Galena.................................... 8

Gannett, S. S., work of ...................... 5

Garden................................... 16

Garden quadrangle........................ 16

Geary City ............................... 41

Geary County............................ 22

Gorham ............................... 27

Gove County............................... 22

Grainfield............................. 28

Grant County .............................. 16

Grinnell.................................... 28, 35

${ }_{28}$ Groveland................................... 
H.

Hamilton County

Harper

Harper County

Havana.

Hawthorne.

Hays.

Hays quadrangle.

Heebink, G. E., work of

Herron, W. H., work of.

Hiawatha quadrangle.

Hill quadrangle.

Hilton.

Holliday

Homer.

Hoxie quadrangle........................

Humboldt.

Hund.

Huscher

Hutchinson. . ...........................

Hutchinson quadrangle.

\section{I.}

Independence.

Independence quadrangle

Inman.

Iola.

Iola quadrangle.

$\mathrm{J}$.

Jarbalo.

Jefferson County

Jewell County.

Johnson.

Johnson County.

Johnstown.

Joplin district.

Junction City.

Junction City quadrangle...................

K.

Kackley

Kanopolis.

Kansas City.

Kanses City uuadran \& Springfeld Ry....

Kansas City, Wyandotte \& Northwestern R. R

Kearney County

R. R.

Kickapoo

Kingman

Kingman County

Kingman quadrangle.

L.

Labette County

La Fontaine.

La Harpe.

Lakin quadrangle.

Lansing.

Lashmet.

Lawrence.

Lawrence quadrangle.

Leavenworth

Leavenworth County.

Leavenworth Junction

Leavenworth quadrangle.
Page.

Lecompton.............................. 36,37

Liberty . ................................. 11

Logan County........................... 22

Longford ............................... 25

Lovewell................................. 26

M.

McAllaster.............................. 38

McFarlane, M. C., work of.................. 16

McPherson.......................... 28

McPherson County..........................

Manchester............................... 25

Manhattan ............................... 29

Mankato quadrangle....................... 35

Maps of quadrangles, list of................. 7

Marshall, R. B., work of................... 5

Medora................................. 29

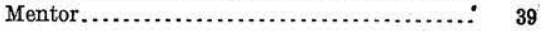

Miltonvale............................ 25

Minneapolis quadrangle.................. $\quad 35$

Missouri, Kansas \& Texas Ry.............. 9

Missouri Pacific Ry..... 21, 26, 27, 30, 31, 33, 34, 35, 42

Monbeck, R. R., work by................ 21

Monotony ................................... 39

Monument.............................. $\quad 36$

Morse................................... 36

Mount Pleasant.......................... 15

N.

Nearman.............................. 31

Neodesha............................... 10

Neosho County .......................... 8

New Cambria.......................... 38

Newington............................. 36

Nodaway............................. 42

o.

Oak Hill.............................. ${ }^{25}$

Oakley................................... 36

Oakley quadrangle....................... 35

Oak Mills................................ 14,37,42

Ogallah................................. 26

Ogden................................... 29

Olathe.................................... 36

Olathe quadrangle........................ 36

Oneonta................................... 26

Oskaloosa quadrangle..................... 12,36

Ottawa County............................

P.

Page City ................................ 35, 38

Palermo.............................. 41

Parnell............................... 16

Parsons quadrangle.......................... 9

Pleasant Ridge........................... 13,14

Pomeroy .................................. 31

Popes station .......................... 32

Pottawatomie County..................... $\quad 22$

Potter.................................. 14, 15

Portersville..................... 9

Preston, Nebr...............................

Pretty Prairie........................... 32

Q.

Quintaro............................... 31

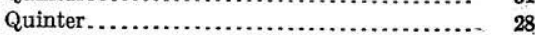


R.

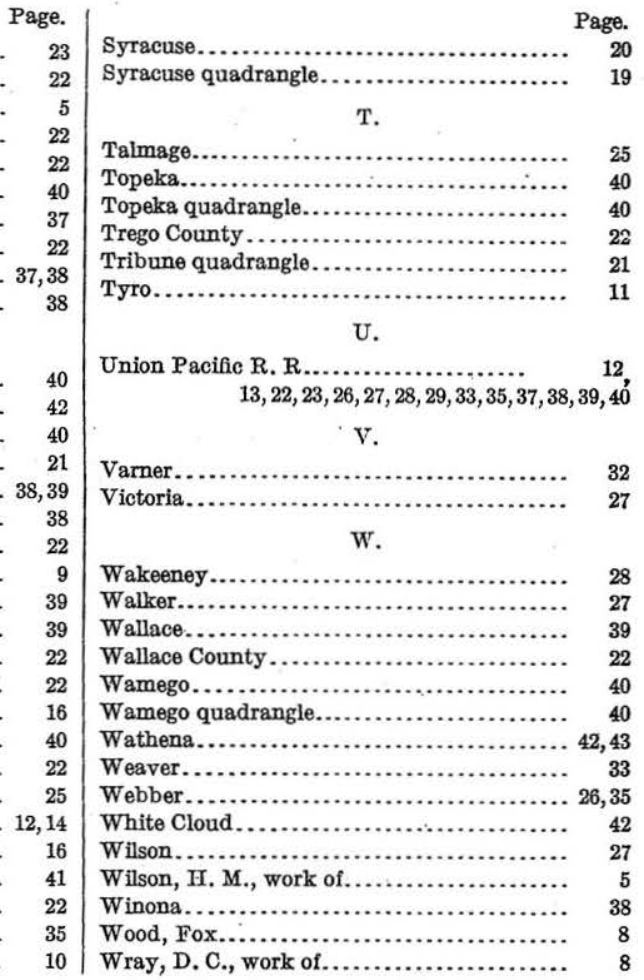

Rago ..............................

Reno County.

Renshawe, J. H., work of.

Republic County.

Riley County.

Rossville.

Russell.

Russell County

Russell quadrangle.........................

Russell Springs quadrangle.

$\mathrm{s}$.

St. George

St. Joseph quadrangle.

St. Marys.

Salem.

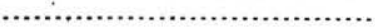

Salina quadrangle.

Saline County.

Savonburg.

Sharon Springs.

Sharon Springs quadrangle

Shawnee County.

Sheridan County

Sherlock.

Silver Lake.

Solomon

Spring.

Springdale.

Stanton County

Sugar Lake station.

Sumner County

Superior, Nebr.

Sycamore.
0

\section{LIBRARY TEXAS TECHNOLOGICAL COLLEGE LUBBOCK, TEXAS}



Lithomount

Pamphlet

Binder

Gaylord Bros. Inc.

Makers

Syracuse, N. Y.

PAT. JAN 21, 1909 
